2011

\title{
Tangled Up in Law: The Jurisprudence of Bob Dylan
}

Michael L. Perlin

New York Law School, michael.perlin@nyls.edu

Follow this and additional works at: http://digitalcommons.nyls.edu/fac_articles_chapters

Part of the Civil Rights and Discrimination Commons, Criminal Procedure Commons, and the Law and Philosophy Commons

\section{Recommended Citation}

38 FORD. URB. L.J. 1395-1430 (2011)

This Article is brought to you for free and open access by the Faculty Scholarship at DigitalCommons@NYLS. It has been accepted for inclusion in Articles \& Chapters by an authorized administrator of DigitalCommons@NYLS. 


\title{
TANGLED UP IN LAW: THE JURISPRUDENCE OF BOB DYLAN
}

\author{
Michael L. Perlin*
}

Introduction 1395

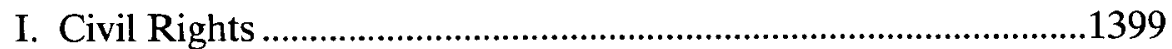

II. Inequality of the Criminal Justice System ..................................1404

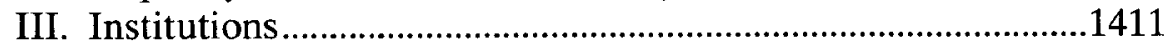

IV. Governmental/Judicial Corruption ..........................................1415

V. Equality and Emancipation ......................................................1417

VI. Poverty, Environment, and Inequality of the Civil Justice

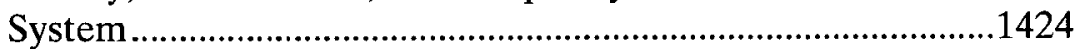

VII. Role of Lawyers and the Legal Process...................................1425

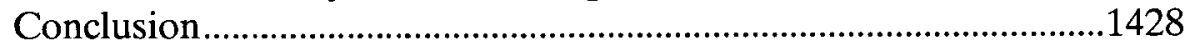

\section{INTRODUCTION}

If all you knew of Bob Dylan's law-related work was Absolutely $S$ weet Marie ("to live outside the law/you must be honest") ${ }^{1}$ or Ballad of a Thin Man ("With great lawyers you have/discussed lepers and crooks"), ${ }^{2}$ you might think that Dylan had little use for the law or the legal system. But you would be wrong. ${ }^{3}$ Dylan has had a robust ca-

" Director, International Mental Disability Law Reform Pro-ject; Director, Online Mental Disability Law Program, New York Law School. The author wishes to thank Kaydi Osowski for her superb research help.

As I was working on the penultimate draft of this article, I had the opportunity to speak to Rubin "Hurricane" Carter at the world premiere of the play Who Is the Enemy?, written by Judge H. Lee Sarokin. Judge Sarokin issued the writ of habeas corpus that freed Carter after twenty-two years in confinement. This Article is dedicated to Carter and to Judge Sarokin, and also to the memory of my friend Michael J. Feuerstein ... we'll meet again/someday on the avenue.

1. Bob Dylan, Absolutely Sweet Marie, on Blonde on Blonde (Columbia Records 1966).

2. Bob Dylan, Ballad of a Thin Man, on Highway 61 Revisited (Columbia Records 1965).

3. See Michael A. Coffino, Genre, Narrative and Judgment: Legal and Protest Song Stories in Two Criminal Cases, 1994 WIS. L. REv. 679, 692 (1994) ("Law has apparently been an object of fascination for Dylan throughout his career, for references to and images of law in his oeuvre are numerous."). For a comprehensive listing, see id. at 693 n.84. 
reer as a litigant, both as a plaintiff ${ }^{4}$ and as a defendant. ${ }^{5}$ He has also been a witness before congressional committees examining copyright legislation. ${ }^{6}$ A careful examination of Dylan's lyrics reveals yet another role - that of a scholar with a well-developed jurisprudence on a range of topics including civil, criminal, public, and private law. The canon is truly tangled up in law. ${ }^{7}$

4. As a plaintiff, Dylan has sought to stop the production of bootlegs. See Todd D. Patterson, The Uruguay Round's Anti-Bootlegging Provision: A Victory for Musical Artists and Record Companies, 15 WIS. INT'L L.J. 371, 383-84 (1997) ("[I]n 1969, after the release of the Dylan bootleg Great White Wonder, attorneys for Columbia, Dylan, and his publishing company obtained a restraining order against one pressing plant which manufactured the bootleg, relying on the doctrine of 'unfair competition and unjust enrichment."'); see also David Schwartz, Strange Fixation: Bootleg Sound Recordings Enjoy the Benefits of Improving Technology, 47 FED. COMM. L.J. 611, 614 (1995).

5. The lyrics in Dylan's Hurricane provoked Patti Valentine, the murder witness, to sue him. See Valentine v. C.B.S., Inc., 698 F.2d 430 (11th Cir. 1983); BoB DYLAN, Hurricane, on DESIRE (Columbia Records 1975). Dylan was also a defendant in various copyright infringement cases. See generally Damiano v. Sony Music Entm't, Inc., 168 F.R.D. 485 (D.N.J. 1996). Dylan also appears as a third-party in other antitrust litigation focusing on performance rights issues. See Meredith Corp. v. SESAC, LLC, No. 09 Civ. 9177, 2011 WL 856266, at *9 (S.D.N.Y. Mar. 9, 2011) (alleging conspiracy to monopolize market for performance rights to songs in defendant's repertoire):

[P]laintiffs do not allege that Bob Dylan songs are not interchangeable with Neil Young songs (although it is certainly possible that, depending on the circumstance, they are not); rather, they allege that the performance rights to Bob Dylan songs are not interchangeable with the performance rights to Neil Young songs because, like all copyright holders, Dylan and Young only Id. affiliate with one of the three [performing rights organizations]).

6. See Copyright Term Extension Act of 1995: Hearing Before the Comm. on the Judiciary, 104th Cong. 55-56 (1995) (statement of Bob Dylan).

7. On the use of Dylan's lyrics in legal writing, see generally Alex Long, [Insert Song Lyrics Here]: The Uses and Misuses of Popular Music Lyrics in Legal Writing, 64 WASH. \& LEE L. REV. 531 (2007). For what is probably the most creative use of Dylan's lyrics, see Paul Race \& Seth Dornier, ADA Amendments Act of 2008: The Effect on Employers and Educators, 46 WILLAMETTE L. REV. 357, 403-04 (2009). In two sentences, the Article quotes BOB DYLAN, Blowin' in the Wind, on THE FREEWHEElin' BOB Dylan (Columbia Records 1963); BoB Dylan, Positively Fourth Street, on BOB DYLAN's GREATEST HITS (Columbia Records 1967); BOB DYLAN, Shelter from the Storm, on BLOOD ON THE TRACKS (Columbia Records 1975); BOB DYlan, Simple Twist of Fate, on BlOOD ON THE TRACKS (Columbia Records 1975); and Bob Dylan, The Times They Are A-Changin', on The Times They ARe AChANGIN' (Columbia Records 1963):

In a "simple twist of fate," and after 18 years, "senators and congressmen" have finally come to "heed the call" and have refused to continue "turn[ing] [their] head[s]" and "pretending [they] just do[]n't see" that the ADA of 1990 had been reduced to a "creature void of form" and substance .... The Act sought to allow the disabled some "shelter from the storm" in order to 
My friends know the story of how, in 1963, I came to the world of Bob as a seventeen-year-old college freshman. I was visiting Gerde's Folk City on a night when I should have been studying for my Political Science 102 exam. ${ }^{8}$ I abandoned Bob (as did so many other observant and secular Jews) during the Born Again period, and I came back into the fold in the mid-nineties. 9 Some also know how and when and where I had my "A-ha!" moment. I was poolside at Governor Prence Motel in Orleans, Massachusetts, in August 1995. In the midst of writing an article about the Colin Ferguson trial and the right of a mentally ill, yet competent, criminal defendant to represent himself, I realized "dignity was the first to leave" 10 was the perfect beforethe-colon title for my paper. ${ }^{11}$ This realization inspired me to look to other Dylan titles and lyrics for many of the law review articles and book chapters-more than fifty by my most recent count-that I have written over the past fifteen years. ${ }^{12}$

I also began to look at the way that courts used Bob's lyrics ${ }^{13}$ and to think about how, if we took the long view, Bob's speculations

finally "stand inside [the] shoes" of the non-disabled Americans so they

might feel that they are "on the side that's winning."

Race \& Dornier, supra, at 403.

8. See Nick Paumgarten, Ladder of the Law: Another Side of Bob Dylan, THE NEw YoRKER (Nov. 18, 2002) http://www.newyorker.com/archive/2002/11/18/021118 ta_talk_paumgarten. For an update of this saga, see Harold Lepidus, Bob Dylan 70th Birthday Countdown - No. 55, 'Bob Dylan and The Law,'EXAMINER.COM (Mar. 30, 2011), http://www.examiner.com/bob-dylan-in-national/bob-dylan-70th-birthday-cou ntdown-no-55-bob-dylan-and-the-law.

9. See generally Michael L. Perlin, Oh Mercy: Blood on the Cusp, 1 MonTAGUe Street 13 (2009) [hereinafter Perlin, Oh Mercy].

10. Bob Dylan, Dignity, on Bob Dylan's Greatest Hits Volume 3 (Columbia Records 1994).

11. Michael L. Perlin, "Dignity Was the First to Leave": Godinez v. Moran, Colin Ferguson, and the Trial of Mentally Disabled Criminal Defendants, 14 BEHAV. SCI. \& L. 61 (1996) [hereinafter Perlin, "Dignity Was the First to Leave'].

12. For a sample, see Publications of Professor Perlin, NEW YORK LAw SCHOOL, http://www.nyls.edu/faculty/faculty_profiles/michael_1_perlin?action=view_publicatio ns.

13. See Michael L. Perlin, "With Great Lawyers You Have Discussed . . ": References to Bob Dylan in Published Legal Cases, ON THE TRACKs, Spring 2005, at 15. In judicial opinions, the most quoted song lyrics are, "you don't need a weatherman to know which way the wind blows." Bов DYLAN, Subterranean Homesick Blues, on BRINGING IT ALL BACK HOME (Columbia Records 1965) (discussing when expert testimony is needed or whether judicial notice can be taken without such testimony). See, e.g., Latino Issues Forum v. EPA., 558 F.3d 936, 949 (9th Cir. 2009) (Thomas, J., concurring) (quoting BOB DYLAN, Idiot Wind, on BLOOD ON THE TRACKS (Columbia Records 1975)) (discussing the impact of particulate air pollution); United States v. Bullock, 454 F.3d 637, 638 n.1 (7th Cir. 2006) ("It may be true he's got a sentence to serve/But ninety-nine years, he just don't deserve" (quoting BOB DYLAN, Percy's 
about the legal system could be viewed as a coherent and structural jurisprudential philosophy.

Bob's lyrics reflect the work of a thinker who takes "the law" seriously in multiple iterations - the role of lawyers, the role of judges, the disparities between the ways the law treats the rich and the poor, the inequality of the criminal and civil justice systems, the corruption of government, the police, the judiciary, and more. Of course, there is no question that many of Bob's lyrics are, to be charitable, "obscure." (The frequent use of the word "mystical" in lyrical analyses seems to be a code word for obscurity.) And Bob being Bob, we will never know exactly what means what. But even in this context, many of Bob's songs about law are "crying [out to us] like a fire in the sun."14

In this Article, I will try to create a topography of Bob-asjurisprudential scholar by looking at selected Dylan songs in these discrete areas of law (and law-and-society): civil rights; inequality of the criminal justice system; institutions; governmental/judicial corruption; equality and emancipation (political and economic); poverty, the environment, and inequality of the civil justice system; and the role of lawyers and the legal process. ${ }^{15}$

Song, on BIOGRAPH (Columbia Records 1985)) (responding to a question of excessive sentence); United States v. Greer, 440 F.3d 1267, 1275 (11th Cir. 2006); Bass v. Bd. of Cnty. Comm'rs, 256 F.3d 1095, 1115 (11th Cir. 2001); Rare Earth, Inc. v. Hoorelbeke, 401 F. Supp. 26, 48 (S.D.N.Y. 1975) ("Goodbye's too good a word, gal/So I'll just say fare thee well/I ain't sayin' you treated me unkind/You could have done better but I don't mind/You just kinda wasted my precious time/But don't think twice, it's all right")(quoting BOB DYLAN, Don't Think Twice, It's All Right, on THE FREEWHEELIN' BOB DYLAN (Columbia Records 1963)) (expressing exasperation with counsel for filing state law claims in federal action). The most famous example is undoubtedly, "When you got nothing, you got nothing to lose[.]" Sprint Commc'ns Co. v. APCC Servs., Inc., 554 U.S. 269, 301 (2008) (Roberts, J., dissenting) (quoting BoB Dylan, Like a Rolling Stone, on Highway 61 Revisited (Columbia Records 1965)).

14. Bob Dylan, It's All Over Now, Baby Blue, on BRINGING It All BaCK Home (Columbia Records 1965).

15. I have omitted - for time and space considerations - any discussion of Dylan's songs that deal primarily with issues of war and international affairs (for examples, see Bob DylaN, John Brown, on MTV UNPLUGged (Columbia Records 1995); BoB Dylan, Masters of War, on THE FreEWHEELIN' BOB DyLAN (Columbia Records 1963); Bob Dylan, With God on Our Side, on The Times They Are A-Changin' (Columbia Records 1963)). This grouping of songs (with a footnote to BOB DYLAN, Neighborhood Bully, on INFIDELs (Columbia Records 1983)) is worth an article of its own. See generally Robert H. Snyder, "Disillusioned Words Like Bullets Bark": Incitement to Genocide, Music, and the Trial of Simon Bikindi, 35 GA. J. INT'L \& COMP. L. 645 (2007)(quoting BOB DYLAN, It's Alright Ma (I'm Only Bleeding), on 
Where appropriate, I will also note how his discrete lyrics - often in other songs than the ones that I will be discussing - can be read to reflect specific legal positions, arguments or philosophies. And only limited time will prevent me from sharing when and where I saw him sing each of the songs for the first and/or most recent time (I do cite some I have never seen him sing, alas). ${ }^{16}$

\section{CIVIL RIGHTS}

Dylan has always been seen as a symbol of the civil rights revolution. ${ }^{17}$ Certainly, this is not news. It is also not news that his music has retained its relevancy to civil rights struggles throughout the nearly half-century since he wrote Blowin' in the Wind ("Blowin"). ${ }^{18}$ But

BRINGING IT ALL BACK HOME (Columbia Records 1965) (discussing the Rwandan civil war)).

16. For my most recent posted reviews, see for example, Michael Perlin, Reviews, Philadelphia, Pennsylvania, BoBlinks.com (Aug. 17, 2011), http://boblinks.com /081711r.html\#4; Michael Perlin, Reviews, Asbury Park, New Jersey, BoBlinks.com (Aug. 14, 2011), http://boblinks.com/081411r.html.

17. See, e.g., Adam Gearey, Outlaw Blues: Law in the Songs of Bob Dylan, 20 CARDOZO L. REV. 1401, 1402 n.6 (1999) (describing the roots of Dylan's music in the folk revival and Civil Rights Movement of the early sixties, as a "revival" of "the constitution" (quoting GREIL MARCUS, INVISIBLE REPUBLIC 22 (1997))); Grant Morris, The Greatest Legal Movie of All Time: Proclaiming the Real Winner, 47 SAN DIEGO L. REV. 533, $541 \mathrm{n} .38$ (2010)(characterizing Blowin' in the Wind as the "signature song of the civil rights movement"); Michael L. Perlin, "I Ain't Gonna Work on Maggie's Farm No More": Institutional Segregation, Community Treatment, the $A D A$, and the Promise of Olmstead v. L.C., 17 T.M. COOLEY L. REv. 53, 54 n.12 (2000) [hereinafter Perlin, Maggie's Farm] (labeling Boв DYLAN, Only a Pawn in Their Game, on THE TIMEs THEY ARE A-ChANGiN' (Columbia Records 1963), as a civil rights "anthem").

18. See, e.g., Charles Hughes, Allowed to Be Free: Bob Dylan and the Civil Rights Movement, in HIGHWAY 61 REVISITED: BOB DYLAN's ROAD FROM MINNESOTA TO THE WORLD 44, 44 (Colleen Josephine Sheehy \& Thomas Swiss eds., 2009) [hereinafter ROAD FROM MINNESOTA] (discussing Stevie Wonder's spoken introduction to his cover version of Blowin' in the Wind at the Thirtieth Anniversary Tribute Concert in October 1992, making reference to civil rights, Vietnam, Watergate, Steven Biko, and the anti-apartheid movement). Commentators have more recently linked Blowin' in the Wind to the Occupy Wall Street movement. See, e.g., Sarwar Kashmeri, For Wall Street Protestors, Is the Answer Blowing in the Wind?, THEHUFFINGTONPOST.COM (Oct. 18, 2011, 5:00 PM), http://www.huffingtonpost.com/ sarwar-kashmeri/occupy-wall-street_b_1000075.html.

The melody of Blowin' in the Wind probably comes from the African-American spiritual No More Auction Block, a song about the demise of the slave trade in the United Kingdom. See Howard Sounes, Down the HighwaY: The LifE of Bob Dylan 114 (Grove Press 2001); Paul Williams, Bob Dylan, Performing ArTist 1960-1973: THE EARLY YeARS 65-67 (1994 Omnibus Press) [hereinafter WiLliams, EARLY YEARS]. Dylan returned to the topic of slavery two decades later in what I think is his greatest song, Blind Willie McTell. BOB DYLAN, Blind Willie McTell, on 
it is important to note how Dylan's music reflects a vision that combines "gospel redemption with scathing critiques of American society"19 and also serves as a blueprint for the great Civil Rights Act of 1964. ${ }^{20}$ Next, consider the themes of some of Dylan's "civil rights songs."21

Blowin:22 These lines - "how many years can some people exist/Before they're allowed to be free?/Yes, ' $n$ ' how many times can a man turn his head/Pretending he just doesn't see?" and "how many ears must one man have/Before he can hear people cry?/Yes, ' $n$ ' how many deaths will it take till he knows/That too many people have died?"23 - probably encapsulate the heart and the soul of the Civil Rights Movement in the early 1960s as well as anything that has ever (or ever will be) written about this time. I think Howard Sounes was absolutely right when he characterized Blowin' as 'the foundation

The BoOtleg Series Volumes 1-3 (RARE AND UnREleased) 1961-1991 (Columbia Records 1991) ("see the ghost of slavery ships"); see also, Robert Reginio, "Nettie Moore" and the Cultural Economy of Race in Bob Dylan's Late Albums, in ROAD From Minnesota (discussing how Nettie Moore, Bob Dylan, Nettie Moore, on MODERN TIMES (Columbia Records 2006), reflects "the lament of a slave who is powerless to control the direction of his life"). Dylan, of course, refers to "slaves" in other, more metaphoric contexts as well. See BOB DYLAN, Tangled Up in Blue, on BLOOD ON THE TRACKS (Columbia Records 1975) ("Then he started into dealing with slaves/And something inside of him died"); BoB DYLAN, Maggie's Farm, on BRINGING IT ALL BACK HOME (Warner Bros. 1965) ("They sing while you slave and I just get bored").

19. WILliams, EARLY Years, supra note 18, at 45, 47 (discussing Dylan's connection with the civil rights group SNCC and its "radical blend of redemption and reckoning"); see also R. Clifton Spargo \& Anne K. Bream, Bob Dylan and Religion, in The Cambridge Companion to Bob Dylan 87, 97 (Kevin J.H. Dettmar ed., 2009) [hereinafter CAMBRIDGE COMPANION] ("[T]he post-Watergate hunger for redemption and institutional rebirth that led to the election of Jimmy Carter ... was implicit in Dylan's restlessness."). In addition, Bob Dylan discusses the racially-motivated hangings in Duluth, Minnesota, in Desolation Row. BOB DYLAN, Desolation Row, on Highway 61 Revisited (Columbia Records 1965); see also Robert Polito, Highway 61 Revisited (1965), in CAMBRIDGE COMPANION, supra, at 137, 141; Dave Hoekstra, Dylan's Duluth Faces up to Its Past, ChiCAGo Sun-Times (July 1, 2001).

20. 28 U.S.C. $\S 1447$ (2006).

21. In this section, I am only including a handful of Dylan's songs. This choice should not be read to indicate that I think these are the only Dylan songs that reflect civil rights themes, only that the themes in these songs are not susceptible to serious misinterpretation. Dylan may have famously said, prior to an early performance of Blowin', "I don't write protest songs," but there is not a shred of evidence that he ever expected anyone to take this sentiment seriously. See Clinton Heylin, BOB DYLAN: BEHIND THE SHADEs Revisited 93 (2001); see also Craig McGregor, Bob DYLAN: A RETROSPECTIVE 1, 4 (Craig McGregor ed., 1972)("Everybody knows there are no protest songs any longer." (quoting Dylan from a 1960s interview)).

22. DYLAN, Blowin' In The Wind, supra note 7.

23. Id. 
stone of Bob's career and a catalyst of the singer-songwriter revolution." ${ }^{24}$ And I do not think we can ever underestimate the significance of the link between the pop cultural revolution and the civil rights revolution.

Times. $^{25}$ Dylan wrote this song in 1963 , as Congress was heatedly debating the Civil Rights Act of 1964. This verse is among the most verismo lyrics of his career:

Come senators, congressmen

Please heed the call

Don't stand in the doorway

Don't block up the hall

For he that gets hurt

Will be he who has stalled

There's a battle outside and it is ragin'

It'll soon shake your windows and rattle your walls

For the times they are a-changin ${ }^{26}$

Tim Riley concludes that Times "defined a generation's values simply by articulating its potential."27 Times forever linked the Civil Rights Movement and the folk music movement. ${ }^{28}$ Oliver Trager characterizes it as a "clarion call to left-wing political activism throughout the $1960 \mathrm{~s}, " 29$ and I think that is absolutely right. I am sure many others heard it the same way that I did in my college dorm back then.

Oxford. $^{30}$ There is little question that Oxford Town was inspired by James Meredith's enrollment as the first African-American student at the University of Mississippi, a "crucial turning point in the civil rights movement." 31 There is little ambiguity about these lyrics. ${ }^{32}$

24. SOUNES, supra note 18 , at 118 .

25. Dylan, The Times They Are A-Changin', supra note 7.

26. $I d$.

27. TIM RILEY, HARD Rain: A DYLAN COMMENTARY 73 (1992).

28. Id. at 72 .

29. Oliver Trager, Keys to the Rain: The Definitive Bob Dylan EncycLOPEDIA 626 (2004).

30. Bob Dylan, Oxford Town, on The Freewheelin' Bob Dylan (Columbia Records 1963).

31. TrAGER, supra note 29, at 476-77 (2004). Meredith was a third-year student at Columbia Law School when I was a first-year student. I still regret that I was too shy to ask him what he thought of the song.

32. He went down to Oxford Town

Guns and clubs followed him down

All because his face was brown

Better get away from Oxford Town

Oxford Town around the bend

He come in to the door, he couldn't get in 
Pawn: ${ }^{33}$ This song was one of several that Dylan chose to sing at the "I Have a Dream" March musical program. ${ }^{34}$ That selection most likely reflects the urgency that Dylan felt to share this song when, indeed, the "whole world was watching." 35 Interestingly, Dylan almost appears to partially absolve Evers' actual killers (as being "pawns" in the violent and deadly game of racial politics), but there is no ambiguity as to his sentiments. ${ }^{36}$

All because of the color of his skin

What do you think about that, my frien'?

Me and my gal, my gal's son

We got met with a tear gas bomb

I don't even know why we come

Goin' back where we come from.

DYLAN, Oxford Town, supra note 30.

33. Bob Dylan, Only a Pawn in Their Game, supra note 17.

34. See Tour, BOB DYLAN, http:/www.bobdylan.com/tour/1963-08-28-lincolnmemorial-march-washington-washington-rights-march (last visited Oct. 4, 2011). Although the official Dylan site lists only three songs, he also sang a fourth (When The Ship Comes In, infra note 35). See Harold Lepidus, Bob Dylan and Martin Luther King, $J_{r}$., EXAMINER.COM (Jan. 14, 2010), http://www.examiner.com/bob-dylan-innational/bob-dylan-and-martin-luther-king-jr. I was there. I remember.

Dylan later wrote a song, in part, about Dr. King's death:

Another man from Atlanta, Georgia

By name of Martin Luther King

He shook the land like the rolling thunder

And made the bells of freedom ring today

With a dream of beauty that they could not burn away

Just another holy man who dared to make a stand

My God, they killed him.

BoB DyLAN, They Killed Him, on KNOCKED OUT LOADED (Columbia Records 1986).

35. I self-consciously use this phrase from BOB DYLAN, When the Ship Comes In, on THE TIMES They ARE A-ChAngIN' (Columbia Records 1963), a lyric that later became a regular protest chant during Vietnam War protests. See generally Todd Gitlin, THE WhOlE WORLD Is Watching: MASS MEDIA IN THE MAKING AND UNMAKING OF THE NEW LEFT (1980).

36. See generally AdAM Nossiter, Of LONG MEMORY: MisSisSiPPI AND THE MURDER OF MEDGAR EVERS (2002).

A bullet from the back of a bush took Medgar Evers' blood

A finger fired the trigger to his name

A handle hid out in the dark

A hand set the spark

Two eyes took the aim

Behind a man's brain

But he can't be blamed

He's only a pawn in their game

A South politician preaches to the poor white man

"You got more than the blacks, don't complain.

You're better than them, you been born with white skin," they explain. 
Emmett Till. ${ }^{37}$ This song is "a straightforward, emotionally-charged narrative account of both the brutal slaying of fourteen-year-old Emmett Till and of the scandalous failure of American justice to punish his killers." ${ }^{38}$ As with Pawn ${ }^{39}$ and Oxford Town, ${ }^{40}$ the lyrics are unambiguous. ${ }^{41}$

Dylan's judicial philosophy on questions of civil rights is crystal clear. If the lyrics of these songs are to be "translated" into legal arguments, he locates himself (explicitly, in the case of Times) ${ }^{42}$ as a supporter of legislation that provides equal rights for racial minorities in matters including: access to education, ${ }^{43}$ the right to protest peacefully, ${ }^{44}$ and simply, the right "to live in the world." 45 Blowin ${ }^{46}$ and Times $^{47}$ were written at a time when Jim Crow laws were still com-

And the Negro's name

Is used it is plain

For the politician's gain

As he rises to fame

And the poor white remains.

Dylan, Only a Pawn in Their Game, supra note 17.

37. Bob Dylan, The Death of Emmett Till, on The Bootleg Series Volume 9-THE WITMARK DEMOS: 1962-1964 (Columbia Records 2010).

38. TRAGER, supra note 29 , at 131 . The case ultimately led to federal legislation that provides for funding and resources for the investigation and prosecution of unresolved, racially motivated murders from the Civil Rights Era. See 28 U.S.C. $\$ 509$ (2006). See generally Barbara A. Schwabauer, The Emmett Till Unsolved Civil Rights Crime Act: The Cold Case of Racism in the Criminal Justice System, 71 OHIO ST. L.J. 653 (2010).

39. DYLAN, Only a Pawn in Their Game, supra note 17.

40. DYLAN, Oxford Town, supra note 30.

41. 'Twas down in Mississippi not so long ago

When a young boy from Chicago town stepped through a Southern door

This boy's dreadful tragedy I can still remember well

The color of his skin was black and his name was Emmett Till

Some men they dragged him to a barn and there they beat him up

They said they had a reason, but I can't remember what

They tortured him and did some things too evil to repeat

There were screaming sounds inside the barn, there was laughing sounds out on the street.

DYLAN, The Death of Emmett Till, supra note 37.

42. Dylan, The Times They Are A-Changin', supra note 7.

43. DyLAN, Oxford Town, supra note 30.

44. DYLAN, Blowin' in the Wind, supra note 7.

45. Jacobus tenBroek, The Right to Live in the World: The Disabled in the LaW of Torts, 54 CAL. L. REV. 841,848 (1966). Dylan's treatment of other minorities is slightly more ambiguous. See infra notes $213-15$ and accompanying text.

46. DYLAN, Blowin in the Wind, supra note 7.

47. Dylan, The Times They Are A-Changin', supra note 7. 
mon in the South and border states. ${ }^{48}$ It may sound odd to anyone born after 1970, but I believe, with my heart and soul, that the civil rights movement would not have captured the "hearts and minds" 49 of the American public as it did had Bob Dylan never existed. ${ }^{50}$

\section{INEQUALITY OF THE CRIMINAL JUSTICE SYSTEM}

Even if Dylan had only written Hurricane $e^{51}$ and The Lonesome Death of Hattie Carroll ("Hattie Carroll'), ${ }^{52}$ he would have had more of an impact on the way that the American public thinks about the criminal justice system than all the professors of criminal law and procedure (including myself) put together. I say this not to be provocative or aggressive, but to state a simple truth. These two songs, while written only eleven years apart, are seemingly from different eras. They brutally force us to confront the corruption of the American judicial system in cases of racially-charged crimes in ways that law review articles or classroom lectures simply cannot equal. ${ }^{33}$

Hattie Carroll was a fifty-one-year-old, black hotel worker who was struck with a cane at a Baltimore, Maryland charity ball by Wil-

\footnotetext{
48. My students are stunned when I tell them that at Delaware rest stops in 1960, water fountains were clearly marked "white" and "colored."

49. Brown v. Bd. of Educ., 347 U.S. 483, 494 (1954).

50. Of course, I do not think this is the only reason. I believe that the vividness heuristic dominates our social and political discourse, for better or worse. See Michael L. Perlin, "And I See Through Your Brain": Access to Experts, Competency to Consent, and the Impact of Antipsychotic Medications in Neuroimaging Cases in the Criminal Trial Process, 2009 Stan. TecH. L. Rev. 4, 24 (2009) (quoting Michael L. Perlin, "The Borderline Which Separated You From Me": The Insanity Defense, the Authoritarian Spirit, the Fear of Faking, and the Culture of Punishment, 82 Iowa L. REV. 1375, 1417 (1997)) (defining vividness heuristic as "a cognitive-simplifying device through which a 'single vivid, memorable case overwhelms mountains of abstract, colorless data upon which rational choices should be made"'). Thus, I agree with Professor Howard Wasserman's conclusion on this issue. See Howard M. Wasserman, Orwell's Vision: Video and the Future of Civil Rights Enforcement, $68 \mathrm{MD}$. L. REV. 600, 615 (2009)("Television coverage of peaceful protesters attacked by police dogs and fire hoses in the civil rights era South is widely credited with rousing northern whites to support the cause of civil rights, leading ultimately to the Civil Rights Act of 1964.").

51. DYLAN, Hurricane, supra note 5.

52. Bob Dylan, The Lonesome Death of Hattie Carroll, on The TIME They ARE A-CHANGIN' (Columbia Records 1963).

53. Also note, the crime at the heart of Hattie Carroll would have likely remained unknown outside of the Baltimore area had it not been for Dylan's song. The crime at the heart of Hurricane became (in)famous because of the persona of the defendant.
} 
liam Zantzinger, a twenty-four-year-old, Maryland tobacco farmer. ${ }^{54}$ Zantzinger, already intoxicated, demanded another drink and complained when Carroll said, "Just a minute, sir." 55 Rubin "Hurricane" Carter was a professional boxer accused of a triple murder committed in a Paterson, New Jersey bar. ${ }^{56}$

When read together, Hattie Carrol $P^{7}$ and Hurricane ${ }^{58}$ are opposite sides of the same coin. Both speak eloquently about the role of race and racism in the criminal justice system. ${ }^{59}$ Hattie Carroll reflects the sort of sentencing decision that, in some ways, ultimately led-for better or worse - to the creation of the Federal Sentencing Guidelines. ${ }^{60}$ Hurricane is a textbook example of how racism can affect

54. Adam Bernstein, William Zantzinger; Infamous After Dylan Song 'Hattie Carroll', WASH. POST, Jan. 10, 2009, at B6.

55. Id. William Zantzinger, the subject of Hattie Carroll, was originally charged with murder, but that was subsequently reduced to manslaughter. He was convicted by a three-judge panel and sentenced to six months in jail. Douglas Martin, W. $D$. Zantzinger, Subject of Dylan Song, Dies at 69, N.Y. TIMES, Jan. 9, 2009, at B8. Zantzinger's name was spelled "Zanzinger" in the song. See DYLAN, The Lonesome Death of Hattie Carroll, supra note 52.

56. Carter was convicted and his conviction was affirmed. See State v. Carter, 255 A.2d 746, 755 (N.J. 1969). He moved for a new trial based upon the State's failure to disclose evidence and the testimonial recantation by the star witnesses against him, but his motions were denied. State v. Carter, 347 A.2d 383, 388 (Passaic County Ct. 1975); State v. Carter, 345 A.2d 808, 829 (Passaic County Ct. 1974). The New Jersey Supreme Court vacated the trial court's decision based on the failure to disclose key evidence. See State v. Carter 354 A.2d 627, 635 (N.J. 1976). Carter was again convicted, and that conviction was upheld by the state Supreme Court by a 4-3 vote. 449 A.2d 1280 (N.J. 1982). Ultimately, his application for a writ of habeas corpus was granted - the court finding that his conviction was "predicated upon an appeal to racism rather than reason, and concealment rather than disclosure." Carter v. Rafferty, 621 F. Supp. 533, 534 (D.N.J. 1985).

57. DYLAN, The Lonesome Death of Hattie Carroll, supra note 52.

58. DYLAN, Hurricane, supra note 5.

59. See Gearey, supra note 17, at 1402 n.7 (opining that Hattie Carroll "contains perhaps the most articulate criticism of a law that claims to be impartial, but operates to protect the rich, white male"); Erik Luna, Transparent Policing, 85 IOWA L. REV. $1107,1117-18$ (2000) ("Modern instances of police racism are seared into the collective memory of minority communities .... They join memories of official brutality and misconduct from the not-so-distant past ... for example, . . the wrongful conviction of Rubin 'Hurricane' Carter while the indelible history of slavery and racial segregation lingers in the background.").

60. See United States v. Bergman, 416 F. Supp. 496, 501 (S.D.N.Y. 1976) ("Our sentencing system, deeply flawed, is characterized by disparity. We are to seek to 'individualize' sentences, but no clear or clearly agreed standards govern the individualization. The lack of meaningful criteria does indeed leave sentencing judges far too much at large."); MARVIN FRANKEL, CRIMINAL SENTENCE: LAW WITHOUT ORDER 78 (1973) ("Left at large, wandering in deserts of uncharted discretion, the judges suit their own value systems insofar as they think about the problem at all."). For more on Judge Frankel's influence on the adoption of the Federal Sentencing Guidelines, 
every aspect of the criminal justice system ${ }^{61}$ : racial disparity in Terry stops; ${ }^{62}$ accuracy of identifications; ${ }^{63}$ one-man "show-up" identifications; ${ }^{64}$ suggestive questioning by the police appealing to racial preju-

see, for example, Kate Stith \& Steve Y. Koh, The Politics of Sentencing Reform: The Legislative History of the Federal Sentencing Guidelines, 28 WAKE FOREST L. REV. 223 (1993).

Dylan has written about sentencing decision-making in other (mostly less wellknown) songs as well. See, e.g., BOB DYLAN, Delia, on WORLd GONE WRONG (Columbia Records 1993) ("Curtis said to the judge, 'What might be my fine?'/Judge says, "Poor boy, you got ninety-nine"'); Вов DYLAN, In Search of Little Sadie, on SELF PORTRAIT (Columbia Records 1970) ("Forty-one days, forty-one nights/Fortyone years to wear the ball and the stripes"); BOB DYLAN, Jim Jones, on GOOD AS I BEEN TO YOU (Columbia Records 1992) ("Now the jury found me guilty/Then says the judge, says he/"Oh, for life, Jim Jones, I'm sending you/Across the stormy sea"); BoB DYLAN, The Shape I'm In, on BEFORE THE FLOOD (Asylum Records 1974) ("I just spent 60 days in the jailhouse/For the crime of having no dough"); BOB DYLAN Sweetheart Like You, on INFIDELS (Columbia Records 1983) ("Steal a little and they throw you in jail/Steal a lot and they make you king"); cf. DYLAN, The Lonesome Death of Hattie Carroll, supra note 52:

In the courtroom of honor, the judge pounded his gavel

To show that all's equal and that the courts are on the level

And that the strings in the books ain't pulled and persuaded

And that even the nobles get properly handled

Once that the cops have chased after and caught 'em

And that the ladder of law has no top and no bottom

Stared at the person who killed for no reason

Who just happened to be feelin' that way without warnin'

And he spoke through his cloak, most deep and distinguished

And handed out strongly, for penalty and repentance

William Zanzinger with a six-month sentence.

When I teach the sentencing guidelines cases in Criminal Procedure, I always begin with these lines from Joey. (concededly my least favorite Dylan song: "What time is it?' said the judge to Joey when they met 'Five to ten,' said Joey. The judge says, 'That's exactly what you get."'). BOB DYLAN, Joey, on DESIRE (Columbia Records 1975).

61. For years, I have wanted to simply print out the lyrics to Hurricane for my Criminal Procedure: Adjudication final and ask students to discuss all issues covered in the course in the context of that song. I have not done it, primarily because I acknowledge it would be fundamentally unfair to those students who were not serious Dylan fans. But still ...

62. "When a cop pulled him over to the side of the road/Just like the time before and the time before that/In Paterson that's just the way things go/If you're black you might as well not show up on the street/'Less you wanna draw the heat." DYLAN, Hurricane, supra note 5.

63. "So they took him to the infirmary/And though this man could hardly see/They told him that he could identify the guilty men." Id.

64. "Four in the mornin' and they haul Rubin in/Take him to the hospital and they bring him upstairs/The wounded man looks up through his one dyin' eye./Says, 'Wha'd you bring him in here for? He ain't the guy!"' Id. 
dice $;{ }^{65}$ conditions of pre-trial confinement; $; 6$ judicial bias; ${ }^{67}$ racial bias in jury selection; 68 tainted publicity; ${ }^{69}$ and conditions of prison confinement. ${ }^{70}$

In Dylan's Visions of Sin, Christopher Ricks begins his "Justice" chapter with an essay on Hattie Carroll, characterizing it as a song "that brings home the falsity of the boast ... that 'the courts are on the level."'71 Paul Williams calls Hurricane "an expression of love for life, love for freedom, love for justice, ... a cry of pain at the existence of injustice, ... via the singer's evident conviction ... that 'testifying' to truth will ultimately dethrone falsehood."72 Hattie Carroll and Hurricane force us to confront the racial disparities that still contaminate the criminal justice system and that led the Supreme Court decades ago to decide a series of criminal procedure cases incorporating the Bill of Rights in state court cases. ${ }^{73}$

65. Arthur Dexter Bradley's still in the robbery game

And the cops are puttin' the screws to him, lookin' for somebody to blame

"Remember that murder that happened in a bar?"

"Remember you said you saw the getaway car?"

"You think you'd like to play ball with the law?"

"Think it might-a been that fighter that you saw runnin' that night?"

"Don't forget that you are white."

Id.

66. "But then they took him to the jailhouse/Where they try to turn a man into a mouse." Id.

67. "The judge made Rubin's witnesses drunkards from the slums." Id.

68. "The D.A. said he was the one who did the deed/And the all-white jury agreed." Id.

69. "And the newspapers, they all went along for the ride." Id.

70. "While Rubin sits like Buddha in a ten-foot cell/An innocent man in a living hell." Id.

71. Christopher Ricks, Dylan's Visions of Sin 221 (HarperCollins Publishers Inc. 2003)(2003). Howard Sounes points out that, in Hattie Carroll, Dylan never explicitly states that Carroll was black and that Zantzinger was white. See SOUNES, supra note 18, at 142. The issue of race is explicitly articulated in Hurricane. "If you're black you might as well not show up on the street/'Less you wanna draw the heat". DYLAN, Hurricane, supra note 5.

72. Paul Williams, Bob Dylan: Performing ARTiSt 1974-1986: The Middle YeARS 49 (Omnibus Press 2004). Williams also compares Hattie Carroll to Hurricane, concluding that Hurricane was written to promote "a more specific and immediate response ( . . . to 'clear his name and give him back the time he's done')." Id. This change may be a reflection of the passage of time, Dylan's maturation, or the fact that Hattie Carroll was written from the perspective of the victim and Hurricane from the perspective of the falsely-accused defendant. See Christopher Hawthorne, Bum Rap, LeGAl AfF., May-June, 2002, at 40, 42 (Dylan's aim in both Hattie Carroll and Hurricane was "to hold the legal system to its own standard of fairness").

73. See, e.g., Michael J. Klarman, The Racial Origins of Modern Criminal Procedure, 99 Mich. L. Rev. 48 (2000); Carol S. Steiker \& Jordan M. Steiker, A Tale of 
But these are not the only songs of Dylan's dealing with inequality in the criminal justice system. ${ }^{74}$ Some are pretty existential (e.g., Political World" :"We're living in times where men commit crimes/And crime don't have a face"). ${ }^{76}$ Some are "enigmatic"77 (e.g., Absolutely Sweet Marie $^{78:}$ "But to live outside the law, you must be honest"). ${ }^{79}$ Some consider the connection between poverty and the roots of crime (Ballad of Donald White ["Donald White"] ${ }^{80}$ : "If I had some education/To give me a decent start/I might have been a doctor or/A master

Two Nations: Implementation of the Death Penalty in "Executing" Versus "Symbolic" States in the United States, 84 TEX. L. REV. 1869, 1916 (2006) ("Indeed, the wholesale criminal procedure revolution wrought by the Warren Court in the 1960s was in large part an attempt to bring outliers - again, mostly southern states - up to a national standard of due process in criminal cases.").

74. Other Dylan lyrics go more to questions of substantive criminal law. On the gradations of homicide, see BOB DYLAN, Frankie and Albert, on GOOD As I BEEN TO You (Columbia Records 1992) ("Judge said to the jury/"Plain as a thing can be/A woman shot her lover down/Murder in the second degree"); on the brainwashing defense, see Bob Dylan, Clean-Cut Kid, on EMPIRE BURLESQue (Columbia Records 1984) ("They said what's up is down, they said what isn't is/They put ideas in his head he thought were his/He was a clean-cut kid/But they made a killer out of him/That's what they did"); on the availability of bail, see BOB DYLAN, I Wanna Be Your Lover, on BIOGRAPH (Columbia Records 1985) ("And the judge says, 'Mona can't have no bond"'). On the other hand, like many of my Criminal Law students over the years, Bob has confused robbery and larceny. See DYLAN, Positively Fourth Street, supra note 7 ("If I was a master thief/Perhaps I'd rob them").

75. Bob DYlan, Political World, on OH MERCY (Columbia Records 1989).

76. I have used Political World as part of a title on multiple occasions. See, e.g., Michael L. Perlin, "Big Ideas, Images and Distorted Facts": The Insanity Defense, Genetics, and the "Political World," in GeneTICs And CRIMINALITY: The Potential MISUSE OF SCIENTIFIC INFORMATION IN COURT 37 (Jeffrey Botkin et al. eds., 1999); Michael L. Perlin, Myths, Realities, and the Political World: The Anthropology of Insanity Defense Attitudes, 24 Bull. AM. ACAD. Psychiatry \& L. 5 (1996); and a different line from the song in the title of an article about the death penalty and mental retardation (Michael L. Perlin, "Life Is in Mirrors, Death Disappears": Giving Life to Atkins, 33 N.M. L. REV. 315 (2003). (2004).

77. Jean Bethke Elshtain, The Perils of Legal Moralism, 20 J.L. \& POL. 549, 549

78. DYLAN, Absolutely Sweet Marie, supra note 1.

79. See also Stephen Ellmann, To Live Outside the Law You Must Be Honest: Bram Fischer and the Meaning of Integrity, 26 N.C. J. INT'L L. \& COM. REG. 767 (2001) (discussing the life of Fischer, a noted South African anti-Apartheid lawyer); William A. Herbert, The Electronic Workplace: To Live Outside the Law You Must Be Honest, 12 EMP. RTS. \& EMP. POL'Y J. 49 (2008) (on off-site employee surveillance). On how this lyric reflects "the space of the outlaw," see Gearey, supra note 17, at 1407. Cf. David Yaffe, Bob Dylan and the Anglo-American Tradition, in CAMBRIDGE COMPANION, supra note 19, at 15, 21 ("Living outside the law would be fine for many in Dylan's audience, a law that was hardly ironclad to begin with.").

80. Bob Dylan, Ballad of Donald White, on Broadside Ballads Volume 6 (Folkways Records 2009). 
in the arts/But I used my hands for stealing/When I was very young/And they locked me down in jailhouse cells/That's how my life begun"). ${ }^{81}$ Some speak to sentencing terms (e.g., Percy's Song ${ }^{82}$ : "He's got a sentence to serve/Turn, turn, turn again/But ninety-nine years/He just don't deserve";83 Drifter's Escape ("Drifter's") ${ }^{84:}$ "Inside, the judge was stepping down/While the jury cried for more"). ${ }^{85}$ Some speak to how unpunished crime can lead to economic windfall (Idiot Wind"6: "They say I shot a man named Gray and took his wife to Italy/She inherited a million bucks and when she died it came to me/I can't help it if I'm lucky"). Some speak to criminal justice issues in songs that focus on other social questions ( $A$ Hard Rain's $A$ Gonna Fall ${ }^{87}$ : "And the executioner's face/is always well hidden") ${ }^{88}$ Others may be read to speak to the question of fairness in a criminal

81. Cf. Jeffrey Kirschmeier, Tear in the Eye of the Law: Mitigating Factors and the Progression Toward a Disease Theory of Criminal Justice, 83 OR. L. REv. 631, 631 n.1 (2004) (quoting this verse from Donald White: "But there's just one question/Before they kill me dead/I'm wondering just how much/To you I really said/Concerning all the boys that come/Down a road like me/Are they enemies or victims/Of your society?").

82. Bob Dylan, Percy's Song, supra note 13.

83. I have used a different lyric from this song in a comparative law article. See Michael L. Perlin, et al., "The Witness Who Saw/He Left Little Doubt": A Comparative Consideration of Expert Testimony in Mental Disability Law Cases in Common and Civil Law Systems, 6 J. Investigative PsyChol. Offender Profile 59 (2009) ("[Percy's Song] is 'a moving tale of backcountry injustice' sung from the point of view of a man who visits a judge in a futile, last-ditch attempt to save his friend from a severe prison sentence"). Over thirty years ago, Percy's Song was characterized as reflecting a world in which "injustice is seen as a universal circumstance." Id. at $59 \mathrm{n} .1$ (citing L. Poague, Performance Variables: Some Versions of Dylan's "It Ain't Me, Babe,"13 J. AEsTHETIC Educ. 79, 96 (1979)).

84. Bob DYlan, Drifter's Escape, on JOHN WESLEY HARding (Columbia Records 1968).

85. Oliver Trager notes that the protagonist of Drifter's is being tried for offenses "unstated and unknown." See TraGER, supra note 29, at 165. But see RILEY, supra note 27 , at 175 , discussing the judge's "ironically kind words to the prisoner he is about to sentence" (quoting Drifter's "'You fail to understand' . . 'Why must you even try?'"). Steven Lubet and Alex J. Lubet have drawn on Drifter's as a reflection of the Senate's acquittal of President Bill Clinton in the latter's impeachment trial. Steven Lubet \& Alex J. Lubet, Intimations of Contemporary Law \& Politics in the Early Oeuvre of Robert A. Zimmerman, 3 GREEN BAG 2D 459, 460 (2000). I expect this may be somewhat tongue-in-cheek.

86. DYLAN, Idiot Wind, supra note 13.

87. Bob Dylan, $A$ Hard Rain's $A$-Gonna Fall, on Free-WheElin' Bob DyLAN (Columbia Records 1963).

88. See Michael L. Perlin, "The Executioner's Face Is Always Well-Hidden": The Role of Counsel and the Courts in Determining Who Dies, 41 N.Y.L. SCH. L. REV. 201 (1996) [hereinafter Perlin, The Executioner's Face]. 
trial proceeding (Dignity ${ }^{89}$ : "Dignity was the first to leave"), ${ }^{90}$ or the fundamental honesty of the trial process (Brownsville Gir" ${ }^{p 1}$ : "Then when I saw you break down in front of the judge and cry real tears/It was the best acting I saw anybody do"). When read together, however, they suggest that the lyrics "when you got nothing, you got nothing to lose" $" 92$ may most succinctly summarize his views. ${ }^{93}$

I have drawn on many other Dylan lyrics for articles that I have written about a variety of other criminal procedure questions as well: forensic ethics, ${ }^{94}$ the incompetency evaluation process, ${ }^{95}$ the treatment of defendants in neonaticide cases, ${ }^{96}$ the insanity defense, ${ }^{97}$ the treatment of sex offenders, ${ }^{98}$ and confessions of crime. ${ }^{99}$ I do not expect to ever run out of these, because of the depths of Dylan's commitment to a criminal justice that is deracialized and fundamentally fair, where "justice [will no longer be] a game."100

89. DYLAN, Dignity, supra note 10.

90. See Perlin, "Dignity Was the First to Leave", supra note 11.

91. BOB DyLAN, Brownsville Girl, on KNOCKED OUT LOADED (Columbia Records 1986).

92. DYLAN, Like a Rolling Stone, supra note 13.

93. See Richard Booth, What Is a Business Crime? 3 J. Bus. \& TECH. L. 127, 134 n.55 (2008) (quoting, DYLAN, Like a Rolling Stone, supra note 13).

94. Michael L. Perlin, "They're an Illusion to Me Now": Forensic Ethics, Sanism and Pretextuality, in Psychology, Crime and Law: Bridging the Gap 239 (David Canter \& Rita Zukauskien eds., 2008).

95. Michael L. Perlin, "Everything's a Little Upside Down, As a Matter of Fact, the Wheels Have Stopped": The Fraudulence of the Incompetency Evaluation Process, 4 Hous. J. Health L. \& Pol'y 239 (2004); Michael L. Perlin, "For the Misdemeanor Outlaw": The Impact of the ADA on the Institutionalization of Criminal Defendants with Mental Disabilities, 52 ALA. L. REv. 193 (2000) [hereinafter Perlin, "For the Misdemeanor Outlaw"].

96. Michael L. Perlin, "She Breaks Just Like a Little Girl": Neonaticide, the Insanity Defense, and the Irrelevance of "Ordinary Common Sense," 10 WM. \& MARY J. WOMEN \& L. 1 (2003) [hereinafter Perlin, Like a Little Gir].

97. Michael L. Perlin, "Big Ideas, Images and Distorted Facts": The Insanity Defense, Genetics, and the Political World, in Genetics AND CRIMINAlity: The POTENTIAL MISUSE OF SCIENTIFIC INFORMATION IN COURT 37 (J. Botkin et al. eds., 1999); Michael L. Perlin, "The Borderline Which Separated You from Me": The Insanity Defense, the Authoritarian Spirit, the Fear of Faking, and the Culture of Punishment, 82 Iowa L. REv. 1375 (1997).

98. Michael L. Perlin, "There's No Success Like Failure/and Failure's No Success at All': Exposing the Pretextuality of Kansas v. Hendricks, 92 Nw. U. L. REv. 1247 (1998).

99. Michael L. Perlin, "I'll Give You Shelter from the Storm": Privilege, Confidentiality, and Confessions of Crime, 29 LOY. L.A. L. REV. 1699 (1996).

100. DYLAN, Hurricane, supra note 5. 


\section{INSTITUTIONS}

Dylan has written frequently about the soul-draining brutality and repression of American penal institutions. ${ }^{101}$ Walls of Red Wing, ${ }^{102}$ a state facility in Minnesota, ${ }^{103}$ could be used as the text for a course in

101. Dylan rarely wrote about psychiatric institutions. But see BOB DYLAN, When You Gonna Wake Up?, on SLOW TRAIN COMING (Columbia Records 1979) ("your insane asylums are filled"). Nonetheless, I have relied - and continue to rely - on his lyrics for multiple articles about mental disability law in general, and institutional mental disability law in particular. See generally, Michael L. Perlin, "Abandoned Love": The Impact of Wyatt v. Stickney on the Intersection Between International Human Rights and Domestic Mental Disability Law, 35 LAW \& PSYCHOL. REV. 121 (2011); Michael L. Perlin, “And My Best Friend, My Doctor/Won't Even Say What It Is I've Got": The Role and Significance of Counsel in Right to Refuse Treatment Cases, 42 SAN DIEGo L. Rev. 735 (2005) [hereinafter Perlin, Best Friend] (relying on BOB DYLAN, Just Like Tom Thumb's Blues, on Highway 61 Revisited. (Columbia Records 1965)); Michael L. Perlin, "Everybody Is Making Love/Or Else Expecting Rain": Considering the Sexual Autonomy Rights of Persons Institutionalized Because of Mental Disability in Forensic Hospitals and in Asia, 83 U. WASH. L. REV. 481 (2008) (relying on DYLAN, Desolation Row, supra note 19); Michael L. Perlin \& Deborah A. Dorfman, "Is It More Than Dodging Lions and Wastin' Time"? Adequacy of Counsel, Questions of Competence, and the Judicial Process in Individual Right to Refuse Treatment Cases, 2 PsYCHOL. PUB. POL'Y \& L. 114 (1996) (relying on DYlan, When I Paint My Masterpiece, on Bob DYlan's Greatest Hits, Vol. 2 (Columbia Records 1971)); Michael L. Perlin, "Make Promises by the Hour": Sex, Drugs, the ADA, and Psychiatric Hospitalization, 46 DEPAUL L. REV. 947 (1997) (relying on DYLAN, Love Minus Zero/No Limits, on BRINGING IT ALl BACK HOME (Columbia Records 1965)); Michael L. Perlin, "Salvation" or a "Lethal Dose"? Attitudes and Advocacy in Right to Refuse Treatment Cases, 4 J. Prof. PSYCHOL. PraC. 51 (2004)(relying on DYLAN, Shelter from the Storm, supra note 7); Michael L. Perlin, "Simplify You, Classify You": Stigma, Stereotypes and Civil Rights in Disability Classification Systems, 25 GA. ST. U. L. REV. 607 (2009) (relying on BOB DYLAN, AII I Really Want to Do, on ANOTHER SIDE OF BOB DYLAN (Columbia Records 1964)); Michael L. Perlin, "Where the Winds Hit Heavy on the Borderline": Mental Disability Law, Theory and Practice, "Us" and "Them", 31 LoY. L.A. L. REv. 775 (1998) (relying on Bob Dylan, Girl From the North Country, on THE FreewheEliN' BOB DYLAN (Columbia Records 1963)); Michael L. Perlin, "There's Voices in the Night Trying to Be Heard": The Potential Impact of the Convention on the Rights of Persons with Disabilities on Domestic Mental Disability Law, in Evolving Issues IN Discrimination: Social SCience and Legal Perspectives (R. Wiener et al. eds., forthcoming 2011) [hereinafter Perlin, Voices] (relying on BOB DYLAN, Million Miles, on TIME OUT OF MIND (Columbia Records 1997)); Michael L. Perlin \& Heather E. Cucolo, "On Desolation Row": The Blurring of the Borders Between Civil and Criminal Mental Disability Law, and What It Means for All of Us (unpublished manuscript) (on file with authors); Michael L. Perlin \& Henry A. Dlugacz, "It's Doom Alone that Counts:" Can International Human Rights Law Be an Effective Source of Rights in Correctional Conditions Litigation?, 27 BEHAV. SCI. \& L. 675 (2009) (relying on DYLAN, Shelter from the Storm, supra note 7).

102. BOB Dylan, Walls of Red Wing, on THE Bootleg SERIES Volumes 1-3 (RARE AND UNRELEASED) 1961-1991 (Columbia Records 1991).

103. See Paul Anderson, Exploring Alternatives to the Incarceration Crisis, $3 \mathrm{U}$. St. Thomas L.J. 375, 381 (2006) (discussing Walls of Red Wing in this context). 
juvenile reformatory law. The song's verses reflect all the core failings of our correctional system: its treatment of the youngest offenders, ${ }^{104}$ the lack of rehabilitation programs, ${ }^{105}$ the physical conditions of confinement, ${ }^{106}$ the brutality of the guards, ${ }^{107}$ and the inevitability (for most) of re-incarceration. ${ }^{108}$ George Jackson ${ }^{109}$ is a naturalistic tale of

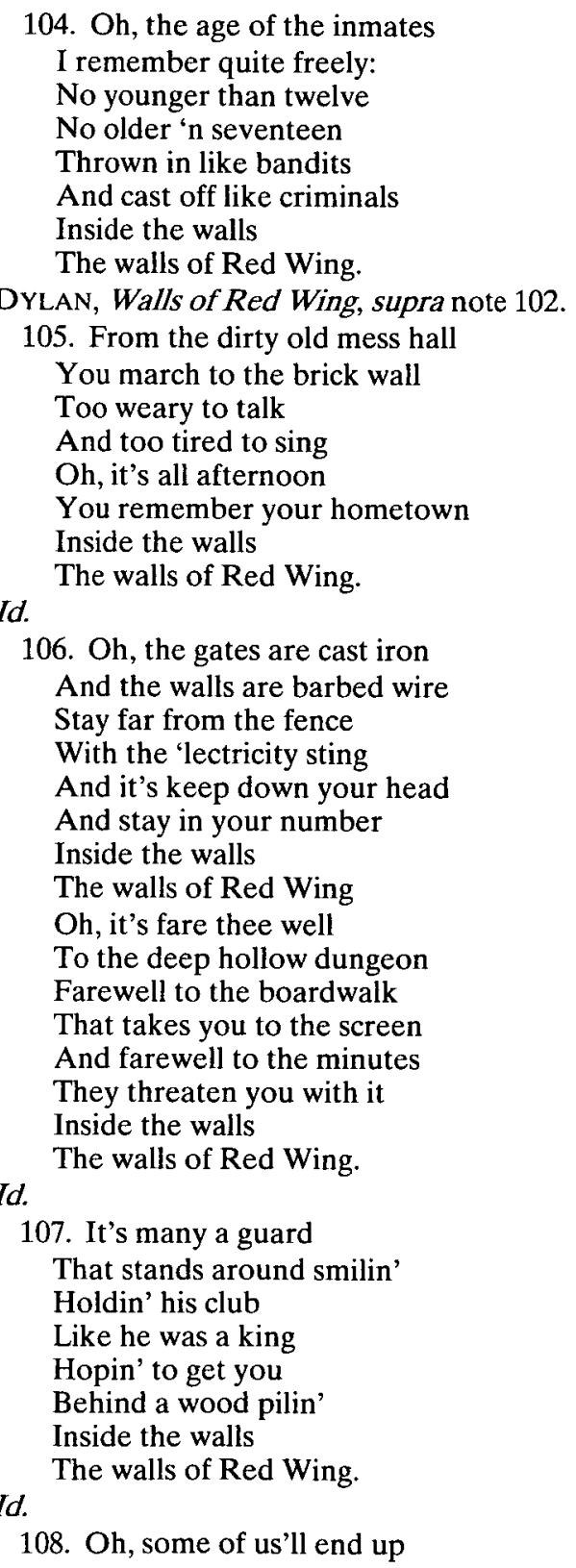


fury that recounts the prison death of Jackson, a Black Panther who was a major figure in radical racial politics in the late 1960s, and whose prison letters evidenced the systemic racist brutality of the

In St. Cloud Prison

And some of us'll wind up

To be lawyers and things

And some of us'll stand up

To meet you on your crossroads

From inside the walls

Id.

The walls of Red Wing.

109. They killed a man I really loved

Shot him through the head

Lord, Lord

They cut George Jackson down

Lord, Lord

They laid him in the ground

Sent him off to prison

For a seventy-dollar robbery

Closed the door behind him

And they threw away the key

Lord, Lord

They cut George Jackson down

Lord, Lord

They laid him in the ground

He wouldn't take shit from no one

He wouldn't bow down or kneel

Authorities, they hated him

Because he was just too real

Lord, Lord

They cut George Jackson down

Lord, Lord

They laid him in the ground

Prison guards, they cursed him

As they watched him from above

But they were frightened of his power

They were scared of his love.

Lord, Lord,

So they cut George Jackson down.

Lord, Lord,

They laid him in the ground.

Sometimes I think this whole world

Is one big prison yard

Some of us are prisoners

The rest of us are guards

Lord, Lord

They cut George Jackson down

Lord, Lord

They laid him in the ground.

BOB DYLAN, George Jackson, on GREATEST HITS VOL. 2 (Columbia Records 1971). 
American prison system. ${ }^{110}$ And, once more, Donald White paradoxically tackles the issue of prison overcrowding and the consequences of that state of affairs:

So I asked them to send me back

To the institution home

But they said they were too crowded

For me they had no room

I got down on my knees and begged

"Oh, please put me away"

But they would not listen to my plea

Or nothing I would say

‥

And so it was on Christmas Eve

In the year of ' 59

It was on that night I killed a man

I did not try to hide

The jury found me guilty

And I won't disagree

For I knew that it would happen

If I wasn't put away. ${ }^{111}$

Of course, there are many more songs in Dylan's oeuvre that deal with prison themes, and more broadly, the cruelty of the criminal justice system. ${ }^{112}$ But these three reflect so many of the issues central to the development of this area of the law. ${ }^{113}$ Again, Dylan is jurisprudentially situated with those who seek to expand the reach of the

110. See GEORGE L. JACKSON, BLOOD IN MY EYE (1972) (a collection of George Jackson's prison letters); GEORGE JACKSON, SOLEDAD BROTHER: THE PRISON LETTERS OF GEORGE JACKSON (1970) (another collection of George Jackson's prison letters); see also MICHAEL GRAY, SONG AND DANCE MAN III: THE ART OF BOB DYLAN 177 (2000) [hereinafter GRAY, SONG AND DANCE MAN] (pointing out the difference between George Jackson and earlier Dylan protest songs by focusing on the couplet, "[the prison guards] were frightened of his power/They were scared of his love"); MiCHAEL GRAY, THE BOB DYLAN ENCYClOPEDIA 346 (2006) (characterizing George L. Jackson as a product of the "post-mystic Dylan").

111. DYLAN, Ballad of Donald White, supra note 80.

112. See Mike Marqusee, Chimes of Freedom: The Politics of Bob Dylan's ART 223 (2003) (referring to BoB DyLAN, Chimes of Freedom, on ANOTHER SidE OF Boв Dylan (Columbia Records 1964); Bob Dylan, I Shall Be Released, on Bов DYLAN's GREATEST HITS VOL. 2 (Columbia Records 1971)); see also DYLAN, Joey, supra note 60 ("He did ten years in Attica, reading Nietzsche and Wilhelm Reich/They threw him in the hole one time for tryin' to stop a strike").

113. See generally JAMES F. ANDERSON, NANCIE J. MANGELS \& LARONISTINE DYSon, Significant Prisoner Rights Cases (2010); Michael L. Perlin \& Henry A. Dlugacz, Mental Health Issues in JaIls and PRISONS: CASES AND Materials (2007); IRA ROBBINS, PRISONERS AND THE LAW (2011). 
Fifth and Eighth Amendments to humanize penal and correctional facilities. ${ }^{114}$

\section{GOVERNMENTAL/JUDICIAL CORRUPTION}

Corruption has always been a theme central to Dylan's work. I drew on License to Kill ${ }^{15}$ for the title of a recent article I wrote about the ways that courts construe neuroimaging evidence - "His Brain Has Been Mismanaged with Great Skill": How Will Jurors Respond to Neuroimaging Testimony in Insanity Defense Cases?16 - in large part because of Oliver Trager's characterization of that song as "a brooding meditation with apocalyptic undertones that takes on corruption and technology run amok." 117 Some ten years ago, in an article about the Americans with Disabilities Act, I quoted the music critic Andrew Muir's vision of Maggie's Farm ("Maggie's"), ${ }^{118}$ as "representing any restricting, corrupt society or system," and a critique of the "personal prisons we all create by denying the freedom of the individual."119 Here, however, I want to focus on governmental corruption, specifically judicial corruption. ${ }^{120}$

114. This effort has become far more difficult since the enactment of the Prison Litigation Reform Act of 1995 (PLRA). See generally, Elizabeth Alexander, Getting to Yes in a PLRA World, 30 PACE L. REv. 1672 (2010); Alison Bril, Rights Without Remedy: The Myth of State Court Accessibility After the Prison Litigation Reform Act, 30 Cardozo L. Rev. 645 (2008).

115. BoB DYLAN, License to Kill, on INFIDELS (Columbia Records 1984).

116. 42 AKron L. REV. 885 (2009).

117. TRAGER, supra note 29, at 376 (emphasis added).

118. Boв DYLAN, Maggie's Farm, supra note 18.

119. Perlin, Maggie's Farm, supra note 17, at 90 (quoting Andrew Muir, Detailed Study of Maggies [sic] Farm, http://reocities.com/athens/forum/2667/maggiesf.html).

120. Dylan does not think too highly of legislators either. See, e.g., BOB DYLAN, No Time To Think, on STREET LeGAL (Columbia Records 1978)("Fools making laws for the breaking of jaws"); DYLAN, When You Gonna Wake Up?, supra note 101 ("You got gangsters in power and lawbreakers making rules"). On police corruption, besides Hurricane, Dylan, supra note 5, see, e.g., BOB Dylan, Man on the Street, on THE Bootleg SERIES Volumes 1-3 (RARE AND UNRElEASED) 1961-1991 (Columbia Records 1991) ("The p'liceman come and he looked around/'Get up, old man, or I'm a-takin' you down'/He jabbed him once with his billy club/And the old man then rolled off the curb/Well, he jabbed him again and loudly said/"Call the wagon; this man is dead'). On "the authorities," see DyLAN, Just Like Tom Thumb's Blues, supra note 101 ("Now all the authorities/They just stand around and boast/How they blackmailed the sergeant-at-arms/Into leaving his post"). On the role of prosecutorial agencies, see DYLAN, Subterranean Homesick Blues, supra note 13 ("the phone's tapped anyway/Maggie says that many say/They must bust in early May/Orders from the D.A."). For his views on lawyers, see infra Part VII. 
Five songs effectively illustrate the point ${ }^{121}$ : Seven Curses, ${ }^{122}$ It's Alright Ma (I'm Only Bleeding),'123 Lily, Rosemary, and the Jack of Hearts ("Lily");124 High Water (For Charlie Patton) ("High Water"); ${ }^{25}$ and Most Likely You Go Your Way (And I'll Go Mine) ("Most Likely"). ${ }^{126}$ Seven Curses ${ }^{127}$ - likely inspired by Judy Collins' song Anathea ${ }^{128}$ and Shakespeare's Measure for Measure ${ }^{129}$-is the story of a "reactionary, corrupt," 130 "treacherous,"131 "cruel"132 judge who promises a girl that he will spare her father from the sentence of death if she will have sex with him, but after having sex with her, orders that her father be hanged nonetheless. ${ }^{133}$ It's Alright $\mathbf{M a}^{134}$ talks of "Old lady judges ... [who] push fake morals." 135 In Lily, the financially-corrupt judge not only has pre-judged the case, ${ }^{136}$ but also he is inebriated ("The hangin' judge came in unnoticed and was being wined and dined/... He went to get the hangin' judge, but the han-

121. There are, of course, others in the canon that make similar points. See, e.g., BoB Dylan, Jokerman, on BRINGING IT ALl BACK HOME (Columbia Records 1965) ("False-hearted judges dying in the webs that they spin").

122. Bob Dylan, Seven Curses, on The Bootleg Series Volumes 1-3 (Rare AND UNRELEASED) 1961-1991 (Columbia Records 1991).

123. DYLAN, It's Alright Ma (I'm Only Bleeding), supra note 15.

124. BoB Dylan, Lily, Rosemary, and the Jack of Hearts, on BLOOD ON THE TraCKs (Columbia Records 1975).

125. Bob Dylan, High Water (for Charley Patton), on Love AND TheFt (Columbia Records 2001).

126. Bob Dylan, Most Likely You Go Your Way (and I'll Go Mine), on Blonde ON BLONDE (Columbia Records 1966).

127. DyLAN, Seven Curses, supra note 122.

128. Judy COLLINS, Anathea, on Judy COLlins 3 (Elektra 1964).

129. WILliam SHAKESPEARE, MEASURE FOR MEASURE (1623).

130. RILEY, supra note 27, at 79.

131. GRAY, SONG AND DANCE MAN, supra note 110 , at 755 .

132. Gearey, supra note 17 , at 1409.

133. See generally Ricks, supra note 71 , at $233-46$. Other judges in Dylan's canon are dishonest as well. See Dylan, Jokerman, supra note 121 ("False-hearted judges dying in the webs that they spin.").

134. DYLAN, It's Alright Ma (I'm Only Bleeding), supra note 15.

135. I used part of the full verse as the title of an article about sanist judicial (and other) attitudes toward the sexuality of persons institutionalized because of mental disability. See Michael L. Perlin, "Limited in Sex, They Dare": Attitudes Toward Issues of Patient Sexuality, 26 AM. J. ForensIC PsyCHIATRY 25 (2005). Dylan adheres to this image of the mockable judge in his most recent work. See BOB DYLAN, Shake, Shake Mama, on TOGETHER THROUGH LIFE (Special Rider Music \& Ice-Nine Publishing 2009) ("Down by the river Judge Simpson walkin' around/Down by the river Judge Simpson walkin' around/Nothing shocks me more than that old clown.").

136. Cf. Bob Dylan, She's Your Lover Now, on The Bootleg Series Volumes 1-3 (RARE AND UNRELEASED) 1961-1991 (Columbia Records 1991) ("But I ain't a judge, you don't have to be nice to me."). 
gin' judge was drunk") until it is time to carry out the prisoner's execution ("And Rosemary on the gallows, she didn't even blink/The hangin' judge was sober, he hadn't had a drink"). ${ }^{137}$ In High Water, the judge openly and brazenly encourages lawlessness: "Judge says to the High Sheriff/'I want him dead or alive/Either one, I don't care."'138 And in Most Likely, ${ }^{139}$ the judge is both pre-biased and "above the law" ("The judge, he holds a grudge," and "But he's badly built/And he walks on stilts"). ${ }^{140}$

The jurisprudential issue of judicial corruption appears to be much more important to Dylan than to most American legal scholars, ${ }^{141}$ unless they are looking at the judiciary in nations with developing economies. ${ }^{142}$ But Dylan's indictment resonates with those with even a passing interest in some of the judicial scandals that have rocked American state courthouses in recent years. ${ }^{143}$

\section{EQUALITY AND EMANCIPATION}

No analysis of Dylan's attitudes toward the law could be complete without paying some attention to songs that speak to the themes of

137. DYLAN, Lily, Rosemary, and the Jack of Hearts, supra note 124.

138. DYLAN, High Water (for Charley Patton), supra note 125.

139. DYLAN, Most Likely You Go Your Way (and I'll Go Mine), supra note 126.

140. Id.; see Michael Coyle \& Debra Rae Cohn, Blonde on Blonde, in CAMBRIDGE CompanION, supra note 19, at 143, 147 ("[The use of stilts] suggests the artificial eminence that the law gives to such public servants.").

141. See, e.g., Lee Dexter Schnasi, Globalizing: Clinical Legal Education: Successful Under-Developed Country Experiences, 6 T.M. COOLEY J. PRAC. \& ClinICAL L. $129,169-70$ (2003) ("Without sounding overly pious, it was possible to confidently say that judicial corruption is not and has not been a problem of American jurisprudence. While instances of judicial impropriety certainly occur, they are so far and few between to be irrelevant to a discussion of litigation or any other legal tactic.").

142. See, e.g., Douglas W. Dunham \& Eric W. Gladbach, Forum Non Conveniens and Foreign Plaintiffs in the 1990s, 24 BROOK. J. INT'L L. 665, 675-77 (1999) (discussing the judiciary in Guatemala); Shiloh Hoggard, Preventing Corruption In Colombia: The Need For An Enhanced State-Level Approach, 21 ARIZ. J. INT'L \& COMP. L. 577, 581, 613-15 (2004) (discussing the judiciary in Colombia); Schnasi, supra note 141 , at 166 (discussing the judiciary in Moldovia and Serbia). See generally Margaret Y.K. Woo, Law And Discretion in the Contemporary Chinese Courts, 8 PAC. RiM L. \& POL'Y J. 581 (1999) (discussing the judiciary in China).

143. See, e.g., Julia Belian, Hubris, 3 Est. Plan. \& Community Prop. L.J. 1, 1 (Fall 2010) ("While every state surely has had its share of probate scandals, New York may hold a special place because the amount and degree of corruption there seems to dwarf that of every other state."); Ellen C. Brotman \& Jo Rosenberger Altman, Honest Services Fraud: A Rose by Any Other Name, 25 CRIM. Just. 15, 15 (Nov. 2010) (discussing the Luzerne County, Pennsylvania, scandal in which judges were accused of accepting kickbacks from a private juvenile correctional institution for sentencing juveniles to that facility). 
emancipation and equality. I treat these songs separately from those that deal with civil rights, judicial corruption and the criminal justice system since I believe they are broader in scope and more universal in their messages. There are many songs in this cohort, but, for the purposes of this Article, I will focus on Chimes of Freedom ("Chimes"), ${ }^{144}$ My Back Pages ("Pages"), ${ }^{145}$ Maggie's Farm, ${ }^{146}$ and Gates of Eden ("Gates"). ${ }^{147}$

I agree with Robert Shelton that Chimes is Dylan's "most political song" and an expression of "affinity" for a "legion of the abused."148 Besides having used the title of Chimes itself (for an article on the intersection between international human rights law and mental disability law), ${ }^{149} \mathrm{I}$ have used lyrics from the song in the titles of articles and presentations about the potential impact of the Americans with Disabilities Act on persons permanently incompetent to stand trial, ${ }^{150}$ the application of human rights standards to forensic psychology practices, ${ }^{151}$ the application of such standards and therapeutic jurisprudence principles to the conditions of confinement of correctional inmates and detainees, ${ }^{152}$ the need for vigorous advocacy in the implementation and enforcement of the United Nation's Convention on the

144. DYLAN, Chimes of Freedom, supra note 112.

145. Bob Dylan, My Back Pages, on ANOTHER Side of Bob Dylan (Columbia Records 1964).

146. DYLAN, Maggie's Farm, supra note 18.

147. Bob Dylan, Gates of Eden, on BRINGING IT ALL BACK Home (Columbia Records 1965); see also BOB DYLAN, I Am a Lonesome Hobo, on JOHN WESLEY Harding (Columbia Records 1968); Bob Dylan, Only a Hobo, on THe BoOTLEG SERIES Volumes 1-3 (RARE AND UNReleased) 1961-1991 (Columbia Records 1991). I discuss BOB DYLAN, Union Sundown, on INFIDELS (Columbia Records 1983) and BoB Dylan, Ballad of Hollis Brown, on THE TIMES THEY ARE AChANGIN' (Columbia Records 1963) in Part VI of this Article.

148. Robert Shelton, No Direction Home: The Life AND Music of Bob DyLAN 157-58 (1997).

149. See Michael L. Perlin, "Chimes of Freedom": International Human Rights and Institutional Mental Disability Law, 21 N.Y.L. SCH. J. INT'L \& COMP. L. 423 (2002).

150. See Perlin, "For the Misdemeanor Outlaw," supra note 95.

151. Michael L. Perlin, "With Faces Hidden While the Walls Were Tightening": Applying International Human Rights Standards to Forensic Psychology, 7 U.S.CHINA L. Rev. 1 (2010).

152. Astrid Birgden \& Michael L. Perlin, "Tolling for the Luckless, the Abandoned and Forsaked": Community Safety, Therapeutic Jurisprudence and International Human Rights Law as Applied to Prisoners and Detainees, 13 LEGAL \& CRIMINOLOGICAL PSYCHOL. 231 (2008). 
Rights of Persons with Disabilities, ${ }^{153}$ and New York Law School's decision to create a course in criminal law and mental disability. ${ }^{154}$ Each of these articles and presentations focuses on the "countless confused, accused" 155 and, to quote a lyric that I have not yet used in an article title, "the refugees on the unarmed road of flight."156

Dylan's magnificent, apocalyptic language in Chimes cries out for equality and the emancipation of those isolated from the mainstream of society. Mike Marqusee writes that Chimes is "Dylan's most sweeping view of solidarity with all those marginalized by a monolithic society." 157 In my articles, I write about marginalized persons, ${ }^{158}$ ones who are the "discrete and insular minorities" written about in the famous Carolene Products footnote. ${ }^{159}$ I believe that in Chimes, Dylan's legal and political vision about this population is at its most profound.

Most of my scholarship is about mental disability law, and in those articles I inevitably write about what I call sanism and pretextuality. Sanism is an irrational prejudice of the same quality and character of other irrational prejudices that cause (and are reflected in) the prevailing social attitudes of racism, sexism, homophobia, and ethnic bigotry. This prejudice infects jurisprudence and lawyering practices; is largely invisible and largely socially acceptable; is based predominantly upon stereotype, myth, superstition, and deindividualization; and is sustained and perpetuated by our use of a false "ordinary common sense" and heuristic reasoning in an unconscious response to events

153. Michael L. Perlin, "Through the Wild Cathedral Evening": Barriers, Attitudes, Participatory Democracy, Professor tenBroek, and the Rights of Persons with Mental Disabilities, 13 TEX. J. C.L. \& C.R. 413 (2008).

154. Michael L. Perlin \& Heather E. Cucolo, "For the Countless Confused, Accused, Misused, Strung-Out Ones an' Worse": Why a Class in Criminal Law and Mental Disability (Mar. 10, 2010), paper presented at the Annual Conference of the Academy of Criminal Justice Sciences (on file with author).

155. DYLAN, Chimes of Freedom, supra note 112.

156. Compare id. with DYLAN, When You Gonna Wake Up?, supra note 101 ("You got innocent men in jail").

157. MARQUSEE, supra note 112, at 94.

158. I made this commitment explicit years earlier in Michael L. Perlin, Competency, Deinstitutionalization, and Homelessness: A Story of Marginalization, 28 Hous. L. REV. 63, 67-68 (1991), and returned to it more recently in Michael L. Perlin \& John Douard, "Equality, I Spoke That Word/As If a Wedding Vow": Mental Disability Law and How We Treat Marginalized Persons, 53 N.Y.L. SCH. L. REV. 9 (20082009).

159. United States v. Carolene Prods., Co., 304 U.S. 144, 153 n.4 (1938). 
both in everyday life and in the legal process. ${ }^{160}$ Pretextuality refers to the ways in which courts accept-either implicitly or explicitlytestimonial dishonesty and engage similarly in dishonest and frequently meretricious decision-making; specifically where witnesses, especially expert witnesses, show a high propensity to purposely distort their testimony in order to achieve desired ends. ${ }^{161}$

In one of my core articles about sanism and pretextuality, I turned to Pages ${ }^{162}$ for my title and selected "half-wracked prejudice leaped forth" 163 because of its main themes (and the themes of the verse in which it is found) ${ }^{164}$ :

that prejudice leads to hatred; that the world is not "black and white"; that our thoughts and our behaviors are largely driven by unconscious forces-are the same themes that explain sanist and pretextual behavior on the parts of courts, legislators, lawyers, expert witnesses, and all other players in the mental disability law arena. ${ }^{165}$

More recently, I chose '“Equality,' I spoke the word/As if a wedding vow" as a title, ${ }^{166}$ explaining my choice in these words (that I borrowed from an earlier unpublished manuscript):

This lyric may be the reason I went to law school (it was a long time ago, and my memory is a little hazy). I tell it to people, but who knows? The point is that, for many persons, the idea of a legal system that incorporates concepts of the "autonomous individual" has been a myth (or, perhaps, more accurately, a cruel hoax) for centuries. If the "autonomous individual" was truly the legal system's focus, we would not -50 years after Brown, 35 years after Jackson v. Indiana, and 30 years after Roe v. Wade-acknowledge that the disenfranchised and insular minorities that were the subject of the Supreme Court's famous "footnote 4" in the Carolene Products case

160. See Michael L. Perlin, The Hidden Prejudice: Mental Disability on TRIAL 21-58 (2000).

161. Id. at $60-77$.

162. DYLAN, My Back Pages, supra note 145.

163. See Michael L. Perlin, "Half-Wracked Prejudice Leaped Forth": Sanism, Pretextuality, and Why and How Mental Disability Law Developed As It Did, $10 \mathrm{~J}$. CONTEMP. LEgal Issues 3 (1999) [hereinafter Perlin, "Half-Wracked Prejudice'].

164. DyLAN, My Back Pages, supra note 145 ("Half-wracked prejudice leaped forth/'Rip down all hate,' I screamed/Lies that life is black and white/Spoke from my skull. I dreamed.").

165. Perlin, "Half-Wracked Prejudice," supra note 163, at 6. Compare, in a very different context from Dylan's born-again period, BOB DYLAN, When He Returns, on Slow Train COMING (Columbia Records 1979) ("How long can I listen to the lies of prejudice?").

166. See Perlin \& Douard, supra note 158. 
nearly 70 years ago remain, all too often, disenfranchised and insular. ${ }^{167}$

I have used Pages one more time even more recently, in an article on the relationship between the admissibility of neuroimaging evidence in criminal trials and a death row prisoner's competency to be executed 168 because of the way Pages "capture[d] the ambivalence of absolute terms." 169 In the course of that article, I discuss the way that such evidence may have different life-and-death impacts on cases involving indigent defendants and those able to pay for the expensive testing in question. ${ }^{170}$ Again, the question of equality - and how we choose to deal with questions of inequality - is never far from the surface. ${ }^{171}$

In Gates, ${ }^{172}$ Dylan shares his vision of an earthly paradise, a "quest for salvation" 173 or, an "epic-length extrapolation[] on the human condition."174 I relied on Gates for an article asking whether the Supreme Court's decision in the ADA case of Olmstead v. L.C. ${ }^{175}$ would resuscitate the least restrictive alternative ("LRA") doctrine in mental disability law, ${ }^{176}$ concluding that:

[Gates of] Eden is Dylan's demonstration that "[t]he present world is one of illusion." To all too many persons with mental disabilities, the LRA concept has forever been little more than an "illusion." The Olmstead case, by resuscitating the LRA doctrine, may prove to be a vehicle for "salvation" for those inappropriately institutiona-

167. Id. at 13-14 (quoting Michael L. Perlin, “'Equality,' I Spoke That Word/As If a Wedding Vow": Therapeutic Jurisprudence and Social Justice (Mar. 2007), paper presented at conference at John Jay College of Criminal Justice, New York (on file with author)).

168. Michael L. Perlin, "Good and Bad, I Defined These Terms, Quite Clear No Doubt Somehow": Neuroimaging and Competency to Be Executed After Panetti, 28 BEHAV. SCI. \& L. 671 (2010).

169. Id. at 673 .

170. Id. at $680-82$.

171. Mike Marqusee again sees Pages as a reflection of the "inadequacy of liberal response to America's growing social crises" and in this way, as a successor to Hattie Carroll. See MARQUSEE, supra note 112, at 107.

172. DYLAN, Gates of Eden, supra note 147; see RILEY, supra note 27, at 106 ("[T]

173. SHELTON, supra note 148, at 194.

174. BOB SPITZ, DYLAN: A BIOGRAPHY 271 (1988).

175. 527 U.S. 581 (1999).

176. See Michael L. Perlin, "Their Promises of Paradise": Will Olmstead v. L.C. Resuscitate the Constitutional Least Restrictive Alternative Principle in Mental Disability Law?, 37 Hous. L. Rev. 999 (2000) [hereinafter Perlin, "Their Promises of Paradise"]. 
lized. It "promises ... paradise." Whether that promise will be delivered is still far from clear. ${ }^{177}$

Of course, Gates is most famous for its lines "There are no trials inside the Gates of Eden" and "There are no sins inside the Gates of Eden."178 At the conclusion of the article to which I just referred, I focus on the emancipatory content of the "trials" line:

Like so many of Dylan's key lines, this is ultimately ambiguous: Do his words refer to legal trials, the trials of living, or something else? Whichever interpretation (or interpretations) we prefer, Dylan's vision is an egalitarian one ("There are no kings inside the Gates of Eden"), based on pure freedom ("Leaving men wholly, totally free/To do anything they wish to do but die"). ${ }^{179}$

And then there is Maggie's Farm. ${ }^{180}$ Twelve years ago, in his piece on Dylan and the law, Adam Gearey began by focusing on Maggie's Farm:

In a song called Maggie's Farm Bob Dylan sings disparagingly of "Maggie's ma" who lectures her servants on "man and God and law." Although Dylan, himself, can occasionally sound like Maggie's ma, difficult and troubling questions of the possibility of overcoming or opposing the law run through his work. Tracing these questions through Dylan's songs makes it plain that at the heart of his lyrics lies the need to articulate a law above the law that is located in the space between man and God. Dylan repeatedly returns to the question which, dreadfully simplified, could be paraphrased as: "How do I live my life?" This question's relevance to religious or ethical debates is clear; its relevance to legal debates, however, is somewhat obscure. ${ }^{181}$

I actually do not find this question obscure at all. I find, in Maggie's Farm, the heart of Dylan's jurisprudential turns. It is, in Paul Wil-

177. Id. at 1005. I use this verse as the source of the title:

With a time-rusted compass blade

Aladdin and his lamp

Sits with Utopian hermit monks

Side saddle on the Golden Calf

And on their promises of paradise

You will not hear a laugh

All except inside the Gates of Eden.

DYLAN, Gates of Eden, supra note 147.

178. DyLAN, Gates of Eden, supra note 147.

179. See Perlin, "Their Promises of Paradise," supra note 176, at 1054.

180. DYLAN, Maggie's Farm, supra note 18.

181. See Gearey, supra note 17, at 1401. 
liams' phrase - his "declaration of independence." 182 Writing, again, about the Americans with Disabilities Act and the Olmstead case, I used Maggie's Farm as the centerpiece of one of my articles, arguing that, just as it spoke to "emancipation," the ADA and Olmstead spoke to "emancipation" 183 as well. I concluded, perhaps a bit too optimistically: ${ }^{184}$

Olmstead potentially has the capacity to transform and revolutionize mental health law in the same profound ways that Bob Dylan transformed and revolutionized popular culture. If Olmstead is taken seriously, it may change the debate on institutional mental health care, on community treatment, on deinstitutionalization, on the segregation of persons with mental disabilities, ... and perhaps most importantly, on how we feel about persons with disabilities. ${ }^{185}$

As I noted above, ${ }^{186}$ the music critic Andrew Muir sees Maggie's Farm as "representing any restricting, corrupt society or system," and reflecting a critique of the "personal prisons [that] we all create by denying the freedom of the individual." 187 The rejection of these prisons, this corrupt society/system, is the essence of an emancipatory philosophy and is the one that Dylan presents here. ${ }^{188}$

182. WILLIAMS, EARLY YEARS, supra note 18, at 156.

183. Perlin, Maggie's Farm, supra note 17, at 56.

184. Within two years, my enthusiasm was somewhat tempered. See Michael L. Perlin, “What's Good Is Bad, What's Bad Is Good, You'll Find out When You Reach the Top, You're on the Bottom": Are the Americans with Disabilities Act (and Olmstead v. L.C.) Anything More than "Idiot Wind"?, 35 U. MiCH. J. L. REFORM 235 (2001-2002); see also Perlin, Voices, supra note 101 (discussing this change of attitude).

185. Perlin, Maggie's Farm, supra note 17, at 56.

186. See supra text accompanying note 119.

187. Perlin, Maggie's Farm, supra note 17, at 90. It is not coincidental that Dylan played an electric version of Maggie's Farm at the epochal Newport concert in 1965, "the most written about performance in the history of rock \& roll." HEYLIN, supra note 21, at 206; see MARQUSEE, supra note 112, at 141-45; SHELTON, supra note 148, at $210-16$.

188. Cf. David Fraser, If I Had a Rocket Launcher: Critical Legal Studies as Moral Terrorism, 41 HASTINGS L.J. 777, 789 (1990) (using Maggie's Farm opening line epigrammatically to illustrate academicians' adoption of Critical Legal Studies ("CLS") as "Urban Guerrilla Warfare"). A topic for another symposium might be the connection between Dylan's "essentially existentialist philosophy." See Irwin Silber, Topical Song: Polarization Sets In, in McGregor, supra note 21, at 102 (referring to HIGHWAY 61 REVISITED (Columbia Records 1965), and the CLS movement). For a sampling of the copious literature on the relationship between CLS and existentialism in general, see, for example, Gunter Frankenberg, Down by Law: Irony, Seriousness, and Reason, 12 GER. L.J. 300 (2011); Adam Gearey, Anxiety And Affirmation: Critical Legal Studies And The Critical "Tradition(S)," 31 N.Y.U. REv. L. \& SoC. Change 585 (2007); John Henry Schlegel, For Peter, with Love, 36 PePP. L. Rev. 535 (2009); 


\section{POVERTY, ENVIRONMENT, AND INEQUALITY OF THE CIVIL JUSTICE SYSTEM}

Dylan's focus tends to be more on criminal justice issues, but he has also written about inequality and bias in the civil system. In Dear Landlord, it appears that the narrator's landlord has also assumed the role of fact-finder in a tenancy trial. ${ }^{189}$ The song title (and a lyric) has also been appropriated as the title of a law review article arguing that property rights must serve human values. ${ }^{190}$ In Hard Rain, Dylan sets out a vision of an environmental apocalypse, ${ }^{191}$ or the "devastation" of the world. ${ }^{192}$ In I Pity the Poor Immigrant, ${ }^{193}$ he simply sets out the

Chantal Thomas, Critical Race Theory and Postcolonial Development Theory: Observations On Methodology, 45 VILL. L. REV. 1195 (2000).

189. Bob DYLAN, Dear Landlord, on JoHn WesLeY HARding (Columbia Records 1968) ("Dear landlord/Please don't dismiss my case/I'm not about to argue/I'm not about to move to no other place"). There has been speculation as to whether Dear Landlord is really about Dylan's relationship to his manager, Albert Grossman, who was, for a time, his actual landlord in Woodstock, New York. See Trager, supra note 29 , at 129 . Tim Riley disagrees, characterizing the song as "a one-sided argument with God." RILEY, supra note 27, at 181. Christopher Ricks sees it as a speculation on the "burden" of "sin." RICKS, supra note 71, at 369.

190. See Keith Sealing, Dear Landlord: Please Don't Put a Price on My Soul: Teaching Property Law Students that "Property Rights Serve Human Values," 5 N.Y. CITY L. REV. 35 (2002).

191. Dylan, A Hard Rain's A-Gonna Fall, supra note 87; see Perlin, The Executioner's Face, supra note 88, at 236.

192. TRAGER, supra note 29, at 234-36. I have drawn on the song three times for article titles (in pieces dealing with the assignment of counsel to death penalty defendants; the need for forensic psychologists to be culturally competent in death penalty case evaluations; and the relationship among therapeutic jurisprudence, human rights and the role of forensic psychologists in the legal process). See generally Astrid Birgden \& Michael L. Perlin, "Where the Home in the Valley Meets the Damp Dirty Prison": A Human Rights Perspective On Therapeutic Jurisprudence and the Role of Forensic Psychologists in Correctional Settings, 14 AGgRESSION \& VIOLENT BEHAVIOR 256 (2009); Perlin, The Executioner's Face, supra note 88; Michael L. Perlin \& Valerie R. McClain, "Where Souls Are Forgotten": Cultural Competencies, Forensic Evaluations and International Human Rights, 15 PsYCHOL. PUB. POL'Y \& L. 257 (2009). All come from this verse:

I'll walk to the depths of the deepest black forest,

Where the people are many and their hands are all empty,

Where the pellets of poison are flooding their waters,

Where the home in the valley meets the damp dirty prison,

Where the executioner's face is always well hidden,

Where hunger is ugly, where souls are forgotten,

Where black is the color, where none is the number

DYLAN, A Hard Rain's A-Gonna Fall, supra note 87.

It has also been suggested that the "executioner's face" line that I used for my death penalty article also "remains topical ... after Abu Ghraib." Yaffe, supra note 79, at 19. 
plight of one cohort of individuals who come under the umbrella of "the countless confused, accused, misused."194 In North Country Blues, he writes of the complete demise of a mining community. ${ }^{195}$ In Ballad of Hollis Brown, he notes how economic deprivation can lead to senseless crime. ${ }^{196}$ And in Union Sundown, he considers the plight of the underpaid laborer. ${ }^{197}$ Dylan clearly situates himself within the school of the "jurisprudence of economic equality."198

\section{ROLE OF LAWYERS AND THE LEGAL PROCESS}

Dylan seems to be wildly ambivalent about lawyers in general. ${ }^{199}$ In Ballad of a Thin Man, he writes, "With great lawyers you have/Discussed lepers and crooks." 200 In Cry a While, he speculates, "I might need a good lawyer, could be your funeral, my trial." 201 I used the former lyric as the title of an article about the need for clinical law professors to shed themselves of their inherent sanism, ${ }^{202}$ arguing that:

Clinical teachers are professors who are lawyers. And clinical clients, all too often, strike clinical students as being "lepers and

193. BoB DYLAN, I Pity the Poor Immigrant, on JOHN WESLEY HARDING (Columbia Records 1968).

194. DyLan, Chimes of Freedom, supra note 112. The plight of the allegedly illegal immigrant in the justice system should be obvious to anyone reading this Article. See, e.g., American Bar Association, Ensuring Fairness and Due Process in IMMIGRATION PROCEEDINGS (2008).

195. BoB Dylan, North Country Blues, on The Times They ARE ACHANGIN'(Columbia Records 1963) ("What with three babies born/The work was cut down/To a half a day's shift/with no reason/Then the shaft was soon shut/And more work was cut").

196. DyLAN, Ballad of Hollis Brown, supra note 147 ("Your empty pockets tell yuh/That you ain't a-got no friend/Your babies are crying louder/It's pounding on your brain/ . . . Seven shots ring out/Like the ocean's pounding roar/There's seven people dead/On a South Dakota farm").

197. DYLAN, Union Sundown, supra note 147 ("And the car I drive is a Chevrolet/It was put together down in Argentina/By a guy makin' thirty cents a day . . . All the furniture, it says 'Made in Brazil'/Where a woman, she slaved for sure/Bringin' home thirty cents a day to a family of twelve").

198. Martha Davis, The Pendulum Swings Back: Poverty Law in the Old and New Curriculum, 34 FordHAM URB. L.J. 1391, 1395 (2007).

199. For an example of what Dylan sees as the legal process' disinterest in truth, see Bob Dylan, Where Are You Tonight? (Journey Through Dark Heat), on STREET LEGAL (Columbia Records 1978) ("[T] he law looks the other way").

200. DYLAN, Ballad of a Thin Man, supra note 2. Multiple interpretations of this song abound, but I believe Robert Shelton's conclusion that it is about "an observer who does not see" is unassailable. SHELTON, supra note 148, at 197.

201. Bob Dylan, Cry a While, on Love \& TheFT (Columbia Records 2001).

202. See supra text accompanying notes $160-61$. 
crooks." If we, like the eponymous Thin Man, allow ourselves to be "observer[s] who [do] not see," we will fall prey to sanism's corrosive and malignant power. ${ }^{203}$

I used the latter lyric as the title of an article about the international need for quality legal representation in involuntary civil commitment cases. ${ }^{204}$ I concluded that, "For many persons with mental disabilities, the lack of a good lawyer turns their trial into a (legal) funeral."205

I have also used less-obvious Dylan lyrics as titles for articles that deal with what lawyers should do and who lawyers are. I used the lyric, "I was just too stubborn to ever be governed by enforced insanity," from $U p$ To $M e,{ }^{206}$ for the title of an article about the dilemmas faced by lawyers representing criminal defendants in incompetency proceedings and insanity trials. ${ }^{207}$ I used "Baby, look inside your mirror," from Mama, You Been on My Mind, ${ }^{208}$ for the title of an article about how we (lawyers and the rest of society) are willfully blind to the status of lawyers with mental disabilities. ${ }^{209}$ I think it is fair to say that Dylan is fairly agnostic about lawyers as a professional cohort. $\mathrm{He}$ is alternatively suspicious of them (when he feels they are supporting a racist and classist status quo) and respectful (when he feels they are supporting social change).

About eight years ago, Nick Paumgarten interviewed me for a "Talk of the Town" piece in The New Yorker. The article addressed my use of Dylan titles in law review articles. In the interview, I dis-

203. Michael L. Perlin, "You Have Discussed Lepers and Crooks": Sanism in Clinical Teaching, 9 CliniCal L. Rev. 683, 685 (2003) [hereinafter Perlin, Lepers and Crooks].

204. See Michael L. Perlin, "I Might Need a Good Lawyer, Could Be Your Funeral, My Trial": Clinical Legal Education and the Right to Counsel in Civil Commitment Cases, 28 WASH. U. J.L. \& POL'Y 241, 246 (2008).

205. Id.

206. Bob Dylan, Up to Me, on BIOGRAPH (Columbia Records 1985).

207. See Michael L. Perlin, "Too Stubborn to Ever Be Governed by Enforced Insanity": Some Therapeutic Jurisprudence Dilemmas in the Representation of Criminal Defendants in Incompetency and Insanity Cases, 33 INT'L J.L. \& PSYCHIATRY 475 (2010) [hereinafter Perlin, Too Stubborn].

208. Bob Dylan, Mama You Been on My Mind, on The Bootleg Series VoLUMES 1-3 (RARE AND UNRELEASED) 1961-1991 (Columbia Records 1991).

209. Michael L. Perlin, "Baby, Look Inside Your Mirror": The Legal Profession's Willful and Sanist Blindness to Lawyers with Mental Disabilities, 69 U. PITT. L. REV. 589 (2008). 
cussed the jurisprudential schools of procedural justice ${ }^{210}$ and of therapeutic jurisprudence: 211

One such concept is that of procedural justice, which says, basically, that we don't care whether we win or lose as long as we're treated fairly. "Dylan obviously thinks that we are not," Perlin says (see "Dear Landlord"). Another is that of therapeutic jurisprudence, which holds that every legal interaction affects the lives of everyday people (see "The Lonesome Death of Hattie Carroll").212

I have written extensively about therapeutic jurisprudence, ${ }^{213}$ and, to a lesser extent, about procedural justice. ${ }^{214}$ In one of the latter co-

210. See Mary Margaret Giannini, Redeeming an Empty Promise: Procedural Justice, the Crime Victims' Rights Act, and the Victim's Right to Be Reasonably Protected from the Accused, 78 TENN. L. REV. 47, 85 (2010) ("Procedural justice theory generally posits that an individual's evaluation of the fairness of a decision is not based only on the final conclusion reached by decision makers, but also on the process by which the authorities reached that conclusion."). See generally Jonathan D. Casper, et. al., Procedural Justice in Felony Cases, 22 LAw \& SoC'Y REv. 483 (1988); Tom R. Tyler, Does the American Public Accept the Rule of Law? The Findings of Psychological Research on Deference to Authority, 56 DEPAUL L. REV. 661 (2007); Tom R. Tyler, What is Procedural Justice?: Criteria Used by Citizens to Assess the Fairness of Legal Procedures, 22 LAW \& SoC'Y REV. 103 (1988).

211. See Perlin, Like a Little Girl, supra note 96, at 30 n.233 ("Therapeutic jurisprudence presents a new model by which we can assess the ultimate impact of case law and legislation on mentally disabled individuals."). It requires (1) studying the role of the law as a therapeutic agent; (2) recognizing that substantive rules, legal procedures, and lawyers' roles may have either therapeutic or anti-therapeutic consequences; and (3) questioning whether such rules, procedures, and roles can or should be reshaped so as to enhance their therapeutic potential, while not subordinating due process principles. See generally, DAVID B. WEXLER, THERAPEUTIC JURISPRUDENCE: THE LAW AS A THERAPEUTIC Agent (1990); DaVID B. WeXler \& BRUCE J. WINICK, LAW IN A THERAPEUTIC KEY: RECENT DEVELOPMENTS IN THERAPEUTIC JURISPRUDENCE (1996) [hereinafter WeXLER \& WinICK, THERAPEUTIC KEY]; Bruce J. Winick, Civil Commitment: A Therapeutic Jurisprudence Model (2005); David B. Wexler, Two Decades of Therapeutic Jurisprudence, 24 TOURO L. REV. 17 (2008).

212. Paumgarten, supra note 8.

213. See Michael L. Perlin, International Human Rights and Mental DisABILITY LAW: WHEN THE SILENCED ARE HEARD (forthcoming 2011) (manuscript at chapter 10); Birgden \& Perlin, supra note 152; Perlin, Too Stubborn, supra note 207; Michael L. Perlin, Therapeutic Jurisprudence and Outpatient Commitment: Kendra's Law as Case Study, 9 PSYCHOL. PUB. POL'Y \& L. 183 (2003); Michael L. Perlin, Therapeutic Jurisprudence: Understanding the Sanist and Pretextual Bases of Mental Disability Law, 20 New ENG. J. ON CRIM. \& CIV. Confinement 369 (1994); Michael L. Perlin, et. al., Therapeutic Jurisprudence and the Civil Rights of Institutionalized Mentally Disabled Persons: Hopeless Oxymoron or Path to Redemption? 1 PsyCHOL. PUB. POL'Y \& L. 80 (1995) (reprinted in WeXLER \& WINICK, THERAPEUTIC KEY, supra note 211 , at 739 ). 
hort of articles, I focus on the findings of Professor Tom Tyler "215 that perceptions of systemic fairness are driven, in large part, by "the degree to which people judge that they are treated with dignity and respect."216 I believe that Dylan's lyrics about the "ladder of the law"217 are informed by this perception and this spirit.

\section{CONCLUSION}

This Article, of course, is not exhaustive. ${ }^{218}$ I would be remiss if I did not note that Dylan's attitude towards women ${ }^{219}$ has been the subject of some severe criticism over the years. ${ }^{220}$ His attitude toward

214. See, e.g., Perlin \& Dorfman, supra note 101, at 120-21; Perlin, Best Friend, supra note 101, at 746; Perlin, "Their Promises of Paradise," supra note 176, at 1049 n.337.

215. See supra note 210.

216. Michael L. Perlin, A Law of Healing, 68 U. CIN. L. REv. 407, 415 (2000) (quoting Tom R. Tyler, The Psychological Consequences of Judicial Procedures: Implications for Civil Commitment Hearings, 46 SMU L. REv. 433, 442 (1992)); cf. DYLAN, Dignity, supra note 10. Professor Christopher McCrudden has used stanzas from Dignity as the opening to his article on the role of dignity in international human rights law. See Christopher McCrudden, Human Dignity and Judicial Interpretation of Human Rights, 19 EUR. J. INT'L L. 655, 656 (2008) ("So many roads, so much at stake/So many dead ends, I'm at the edge of the lake/Sometimes I wonder what it's gonna take/To find dignity").

217. See Paumgarten, supra note 8; Dylan, The Lonesome Death of Hattie Carroll, supra note 52 and accompanying text.

218. By way of examples, it excludes lyrics that I have used about a range of other legal topics, ranging from pedagogy to tort law. See, e.g., Keri K. Gould \& Michael L. Perlin, "Johnny's in the Basement/Mixing Up His Medicine": Therapeutic Jurisprudence and Clinical Teaching, 24 SEATTLE U. L. Rev. 339 (2000); Michael L. Perlin, "Ain't No Goin' Back": Teaching Mental Disability Law Courses Online, 51 N.Y.L. SCH. L. Rev. 991 (2006); Michael L. Perlin, "They Keep It All Hid": The Ghettoization of Mental Disability Law and Its Implications for Legal Education, 54 ST. LouIs U. L.J. 857 (2010); Michael L. Perlin, "Things Have Changed": Looking at Non-Institutional Mental Disability Law Through the Sanism Filter, 46 N.Y.L. SCH. L. Rev. 535 (2002-2003); Michael L. Perlin, "You Got No Secrets to Conceal": Considering the Application of the Tarasoff Doctrine Abroad, 75 U. CIN. L. REV. 611 (2006); Michael L. Perlin \& Deborah A. Dorfman, "The Sources of This Hidden Pain": Why a Class in Race, Gender, Class and Mental Disability, in Vulnerable POPUlations \& TRANSFORMATIVE LAW TEACHING 313 (2011).

219. See, e.g., DYLAN, When You Gonna Wake Up, supra note 101 ("You got men who can't hold their peace and women who can't control their tongues").

220. See, e.g., Jonathan Lethem, Infidels, in CAMBRIDGE COMPANION, supra note 19, at 160, 164 (calling Sweetheart Like You "an affront to feminists"); Barbara O'Dair, Bob Dylan and Gender Politics, in CAMBRIDGE CoMPANION supra note 19, at 80,84 (characterizing Dylan as a "pre-feminist ... just as confused by [his] own roles in the free world as [he] is by the women who surround [him]"). But see David Yaffe, Not Dark Yet: How Bob Dylan Got His Groove Back, in ROAD From MiNNESOTA, supra note 18, at 197, 206-07 (discussing Dylan's depictions of AfricanAmerican women). There is no question that Dylan's songs often reflect significant 
gays has also received criticism. ${ }^{221}$ Nevertheless, I believe that if we take a broad view of his fifty years of composing and performing music, we find that his core commitments to dignity and equality are by far the predominant themes.

I have been listening to Bob since 1963. I took my kids to see him for the first time in 1995 (when they were eleven and fourteen). I have stood in general-admission audiences and sat in seats not too far from, variously, Patti Smith, Elvis Costello, Geraldo Rivera, and who knows who else. In 2010, I went to a concert with a faculty colleague who was born at about the same time that Blood on the Tracks ${ }^{22}$ was released. I have seen him in Rhode Island with my wife and in Paris with my daughter. I have seen Bob twenty-five to thirty times since

ambiguity on this question. See, e.g., Michael Denning, Bob Dylan and Rolling Thunder, in CAMBRIDGE COMPANION, supra note 19, at 28, 39 (discussing Just Like a Woman). Mike Marqusee speculates that multiple Dylan songs situate Dylan "inside a ménage a trois." MARQUSEE, supra note 112, at 179.

221. See, e.g., Alan Light, Bob Dylan as Performer, in Cambridge Companion, supra note 19, at 55, 64 (discussing "homophobic rants" at some of the born-again era concerts). For what it's worth, I have always thought that Ballad of a Thin Man was really about a gay experience. See DYLAN, Ballad of a Thin Man, supra note 2.

You walk into the room

With your pencil in your hand

You see somebody naked

And you say, "Who is that man?"

You try so hard

But you don't understand

Just what you'll say

When you get home

You hand in your ticket

And you go watch the geek

Who immediately walks up to you

When he hears you speak

And says, "How does it feel

To be such a freak?"

And you say, "Impossible"

As he hands you a bone

Well, the sword swallower, he comes up to you

And then he kneels

He crosses himself

And then he clicks his high heels

And without further notice

He asks you how it feels

And he says, "Here is your throat back

Id.

Thanks for the loan"

222. Bob Dylan, Blood on the Tracks (Columbia Records 1975). 
1994. There will be, I pray, many more concerts and venues to come. 223

I was brought back into the world of Bob (after my self-imposed post-born-again-phase exile) by my then-student and later close friend, Michael J. Feuerstein. Michael's untimely death nearly three years ago left a vacuum in my soul that may never be replaced. ${ }^{224}$ When I titled my competency-to-proceed-pro-se article, Dignity Was the First to Leave:. . ., 225 something clicked. I had been a "real lawyer" for thirteen years before I became a professor. I represented mostly criminal defendants, residents of psychiatric institutions, and correctional facility inmates-individuals that most of the public would see as "lepers and crooks."226 Since I published Dignity ... , I have returned to Bob again and again and again. Of course, it has been fun (and I guess I plead "no contest" to charges of seeking to consciously brand my work). But it has been much more than that. I believe that it is not "useless and pointless knowledge."227 Rather, I see it as a reflection of a near-total consonance between Bob's jurisprudential and political values and the values I seek to assert in my writings.

So, thank you, my friends Sam Levine and Bruce Green, for asking me to participate in this program. And, in Bob's spirit and once more channeling Tombstone, "the tears [you see] on [my] cheek are from laughter." 228

223. I edited an earlier version of this Article on a plane to California in February (a state where my daughter has seen Bob multiple times). On the plane, my wife was listening to the WITMARK DEMOS: 1962-1964 (Columbia Records 2010) as I was listening to Highway 61 Revisited (Columbia Records 1965), both courtesy of Continental's entertainment system. Bob is never - and never will be - far from our lives.

224. See Perlin, Oh Mercy, supra note 9.

225. See Perlin, Dignity Was the First to Leave, supra note 11.

226. See Perlin, Lepers and Crooks, supra note 203.

227. Dylan, Tombstone Blues, on Highway 61 ReVISITED (Columbia Records $1965)$.

228. Id. (emphasis added). 